\title{
EVALUATING SHORT-TERM CLIMATE VARIABILITY IN THE LATE HOLOCENE OF THE NORTHERN GREAT PLAINS
}

Final Topical Report

for the period April 15, 1998, through July 31, 1999

Prepared for:

AAD Document Control

U.S. Department of Energy

Federal Energy Technology Center

PO Box 10940, MS 921-143

Pittsburgh, PA 15236-0940

Cooperative Agreement No. DE-FC26-98FT40320--06

Performance Monitor: Mildred Perry

Prepared by:

Joseph H. Hartman

Energy \& Environmental Research Center

University of North Dakota

PO Box 9018

Grand Forks, ND 58202-9018

99-EERC-09-04

September 1999 


\section{EVALUATING SHORT-TERM CLIMATE VARIABILITY IN THE LATE HOLOCENE OF THE NORTHERN GREAT PLAINS}

\section{PROJECT ACCOMPLISHMENTS}

This literature study investigated methods and areas to deduce climate change and climate patterns, looking for short-term cycle phenomena and the means to interpret them. Many groups are actively engaged in intensive climate-related research. Ongoing research might be (overly) simplified into three categories: 1) historic data on weather that can be used for trend analysis and modeling; 2) detailed geological, biological (subfossil), and analytical (geochemical, radiocarbon, etc.) studies covering the last 10,000 years (about since last glaciation); and 3) geological, paleontological, and analytical (geochemical, radiometric, etc.) studies over millions of years. Of importance is our ultimate ability to join these various lines of inquiry into an effective means of interpretation. At this point, the process of integration is fraught with methodological troubles and misconceptions about what each group can contribute. This project has met its goals to the extent that it provided an opportunity to study resource materials and consider options for future effort toward the goal of understanding the natural climate variation that has shaped our current civilization.

A further outcome of this project is a proposed methodology based on "climate sections" that provides spatial and temporal correlation within a region. The method would integrate cultural and climate data to establish the climate history of a region with increasing accuracy with progressive study and scientific advancement (e. g., better integration of regional and global models). 


\section{TABLE OF CONTENTS}

EXECUTIVE SUMMARY $\ldots \ldots \ldots \ldots \ldots \ldots \ldots \ldots \ldots \ldots \ldots \ldots \ldots \ldots \ldots$

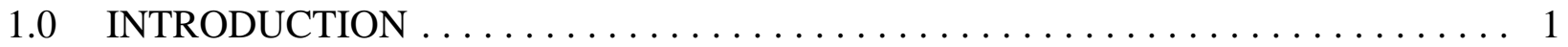

2.0 GOALS AND OBJECTIVES $\ldots \ldots \ldots \ldots \ldots \ldots \ldots \ldots \ldots \ldots \ldots \ldots \ldots$

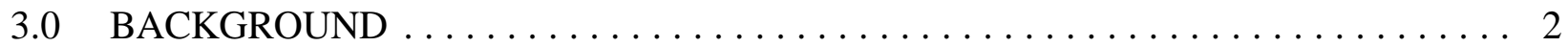

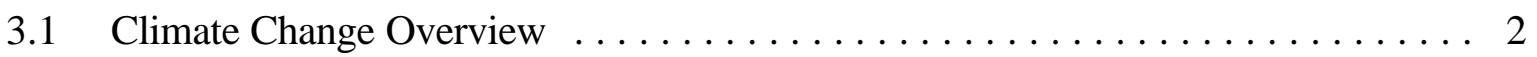

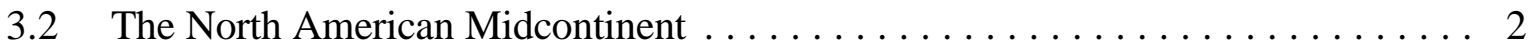

3.2.1 Recent Climate Study in North Dakota . . . . . . . . . . . . . . . . 3

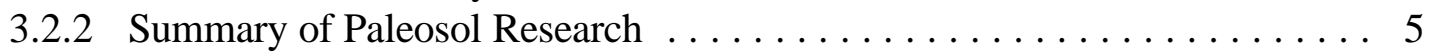

4.0 SCOPE OF WORK: STUDY EXAMPLES OF METHODS AND RESULTS . . . . . . 5

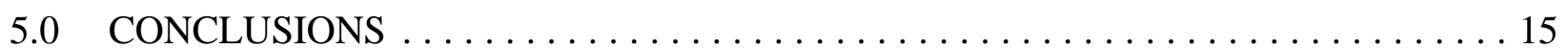

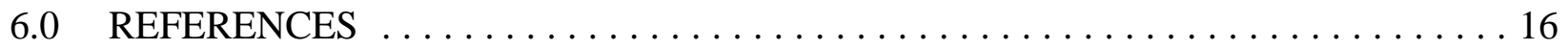

SELECTED CLIMATE PAPERS ORGANIZED BY TOPIC . . . . . . . A Appendix A 


\section{EVALUATING SHORT-TERM CLIMATE VARIABILITY IN THE LATE HOLOCENE OF THE NORTHERN GREAT PLAINS}

\section{EXECUTIVE SUMMARY}

The debate over the importance of anthropogenic effects on the environment cannot be fully appreciated or resolved until human industrial, agricultural, and domestic impacts are understood in the context of natural climate change. Arguments over climate trends need to consider the recent geologic record. Placing events resulting from climatic fluctuations into the context of a span of time greater than human activity provides a more complete basis upon which to interpret human effect on the environment. The importance of a thorough understanding of this natural climate variability is heightened as greater preventive measures are enacted to restrict the release of greenhouse gases into the environment. Because actions taken on behalf of the environment will have global economic impacts, it is imperative that we develop a better understanding of global climate change to determine if modern climate trends are the result of human activity, natural variability, or some combination of these factors.

Clearly, major changes in climate have occurred over geologic time, as well as significant changes during preindustrial civilizations. Ongoing studies indicate that variations in climate may have occurred regularly over the last few thousand years. The debate over the importance of natural climate variability versus anthropogenic causes of climate change cannot be resolved until more is understood of this natural variation. The possibility of short-term geological cycles that indicate significant natural climate variability should be of great interest to the public, relevant industries, and governing bodies.

Short-term climate cycle research requires interdisciplinary integration of geological, paleontological/biological, and analytical methods. Precise temporal frameworks, either as single points that can be tied to larger scenarios or as closely spaced control points where accurate interpolation is possible, are necessary to deduce the pace of climate change and possible patterns. Many of the studies done prior to the 1990s can provide only a general framework, with limited temporal resolution, for interpreting a constantly changing climate. Many useful early studies showing climate trends or patterns have been conducted, but few have the power to resolve the minor variations in climate that play such a significant role in culture stability without actually constituting a major climate shift (e.g., changes in temperature or precipitation that result in drought or flooding).

In midcontinental areas of generally stable semiarid (badlands processes) to subtemperate (e.g., lake basin areas) climate, wetting and drying of sediment drastically affect alluvial and eolian processes, and seasonality is well defined. Investigation of these areas could establish a sound framework for climate change standards as a basis for regional comparisons. Studies that can correlate ecological/vegetational boundaries could provide for an intraregional approach to climate variation and cycle study. 
As a working idea to be further investigated, I propose that "climate sections" be established that serve as a standard of reference for a climate history for a region. This idea is somewhat analogous to concepts of use established in stratigraphy. ${ }^{1,2}$ In stratigraphic studies, stratigraphic sections are chosen that represent type, or reference, examples of a particular formation, range of fossil occurrence, or time boundary. Means of correlation from one area to another are based on whatever appropriate criteria are available, and with sufficient study, events in space and time can be placed into coherent histories. Similarly, climate sections can be established on the basis of criteria that provide the optimum conditions for spatial and temporal correlation within a region. As a result, the climate history can be established and honed to greater accuracy with increasing study and technological advances. These climate sections may also provide an ideal opportunity to integrate cultural data derived from anthropological studies. As culture and climate are highly correlated, a convincing history of climate change may well be possible.

1 North American Commission on Stratigraphic Nomenclature, 1983, North American stratigraphic code: American Association of Petroleum Geologists Bulletin, v. 67, no. 5, p. 841-875.

2 Remane, J., Bassett, M.G., Cowie, J.W., Gohrbandt, K.H., Lane, H.R., Michelsen, O., and Naiwen, W., 1996, Revised guidelines for the establishment of global chronostratigraphic standards by the International Commission on Stratigraphy (ICS): Episodes, v. 19, no. 3. 


\section{EVALUATING SHORT-TERM CLIMATE VARIABILITY IN THE LATE HOLOCENE OF THE NORTHERN GREAT PLAINS}

\subsection{INTRODUCTION}

The debate over the importance of anthropogenic effects on the environment cannot be fully appreciated or resolved until human industrial, agricultural, and domestic impacts are understood in the context of natural climate change. Arguments concerning trends in climate should be placed in the context of the geologic record, where events resulting from climatic fluctuations can be interpreted over a span of time greater than human activity, providing a more meaningful basis upon which to interpret the human effect on the environment. The importance of a thorough understanding of this natural variability is heightened as greater preventive measures are enacted to restrict the release of greenhouse gases into the environment. The debate over the importance of natural climate variability versus anthropogenic causes of climate change cannot be resolved until more is understood of the natural variation. The possibility of short-term geological cycles that indicate the presence of significant natural climate variability should be of great interest to the public, relevant industries, and governing bodies. Clearly, major changes in climate have occurred over geologic time, as well as significant changes during preindustrial civilizations. Ongoing studies indicate that variations in climate may have occurred regularly over the last few thousand years. Because actions taken on behalf of the environment will have global economic impacts, it is imperative that we develop a better understanding of global climate change to determine if modern climate trends are the result of human activity, natural variability, or some combination of these factors.

\subsection{GOALS AND OBJECTIVES}

The goal of this project is to better understand natural climatic variations in the recent past (last 5000 years). The information generated by this work is intended to provide better context within which to examine global climate change. The ongoing project will help to establish a basis upon which to interpret late Holocene short-term climate variability as evidenced in various studies in the northern Great Plains, northern hemisphere, and elsewhere. Finally these data can be integrated into a history of climate change and predictive climate models. This is not a small undertaking. The goals of researchers and the methods used vary considerably. The primary task of this project was literature research to 1) evaluate existing methodologies used in geologic climate change studies and evidence for short-term cycles produced by these methodologies and 2) evaluate late Holocene climate patterns and their interpretations. 


\subsection{BACKGROUND}

\subsection{Climate Change Overview}

Natural climatic variation since the Wisconsinan glaciation (from 10,000 years ago to the present) has been documented through a variety of environmental indicators. Temperature changes during this time, known as the Holocene, of 6E or 7EC are documented (Folland and others, 1991), and their effects on human civilizations cannot be doubted (e.g., Mayans, Anasazi).

\subsection{The North American Midcontinent}

The midcontinent of North America serves as an important barometer to present weather conditions and past climate change in the general absence of oceanic buffers (Leon Osborne, verbal communication, 1999). Climate studies in areas with aquatic reservoirs typically involve evidence of changes in the biota resulting from fluctuations in precipitation, reflecting periods of increased aridity followed by times of more equable climate (Bradbury and others, 1993). For example, variation in the relative percentage of palynomorphs (fossil pollen and spores) (McAndrews, 1966), indicating changes in vegetational patterns, have been widely used to interpret climate change in areas with mixed vegetation types, where lakes or other depositional sinks are relatively common. Diatoms (single-celled plants) and ostracodes (bivalved arthropods) have been used to indicate variation in the salinity of bodies of water in more arid environments, but associated again with semipermanent bodies of water (Laird and others, 1996).

In the southwest and elsewhere, variation in the equability of the climate has been interpreted from the seasonal variations recorded in tree rings. These are some examples of how organisms track seasonal and general climatic variation as a function of habitability in an already wet, or conducive to life, environment.

In semiarid settings, as in western North Dakota, only limited effort has been given to establishing the pattern of climatic variation recorded in cycles of alluvial sedimentation in highly erodible bedrock (Kuehn, 1995; Hartman and others, 1997, 1998; Hartman and Kuehn, 1999). The grass- and badlands of the northern plains conserve few permanent bodies of water to record variation in biotic productivity. These distinctive habitats do, however, record wet and dry periods by decreasing and increasing rates of cut-and-fill deposition in vast tracks of unconsolidated and semiunconsolidated bedrock. Unlike changes in the various biotic components of a diverse ecosystem, which may require substantial lag times to reflect climatic patterns, increased or decreased erosion and deposition may be a direct reflection of wet and dry cycles. As a corollary, badlands sedimentation patterns are such a potentially sensitive environmental indicator that they may be capable of recording short-period cycles and thus provide additional objective information on correlating cause and effect, such as those effects caused by changes hypothesized to occur because of solar activity. 


\subsubsection{Recent Climate Study in North Dakota}

The investigation of climate trends and cycles associated with paleosols (past soils) from western North Dakota and adjacent areas led to a broader understanding of the potential natural variability of the climate across the northern plains. The following discussion (Hartman and others, 1998) on climate and paleosols provides one impetus for further study in this area.

The basic principles concerning the relationship between climate, soils, and geomorphic processes provide the necessary conceptual framework for using paleosols and related analytical data for subsequent interpretations. Climate, particularly insolation and moisture, has a direct influence on vegetation. Together, both climate and vegetation, in the absence of structural, eustatic changes or cultural modifications, are the major driving forces behind the weathering, erosion, transportation, and deposition of sediment. Landscape form is, therefore, determined by the balance between deposition, erosion, and stability (Butzer, 1976; Derbyshire, 1976).

Several basic geomorphic models utilizing the above-mentioned climatic/geomorphic relationships have been developed within the last several decades. For example, during periods when landforms are stable, hillslopes are covered by a protective mat of vegetation, and a balance is established between weathering (soil formation) and valley sedimentation. The weathering of surface sediments during periods of landscape stability produces soils. During periods of landscape instability, vegetation is significantly reduced, if not removed completely. This leads to slope disequilibrium as erosion outpaces soil formation. Disequilibrium results in the total and/or partial truncation of soils, which, in turn, accelerates the lateral transfer of sediment to lower slopes and valley bottoms.

Critical to this project, however, is the hypothesis that at the scale of individual geomorphic landscapes, change can also occur as a result of "complex response" to intrinsic variables (Schumm, 1973). Complex response is an active process in most landscape settings, especially fluvial, and is most acute in highly dynamic landscapes, such as badlands, where geomorphic thresholds are in constant adjustment (Bryan and Yair, 1982). The concept of complex response as a causal factor behind local geomorphic variability is discussed later in this report.

As demonstrated by Langbein and Schumm (1958), slope erosion and/or runoff is most directly affected by precipitation, although temperature is also a key factor, as it greatly affects evapotranspiration. In semiarid regions, including all of western North Dakota, the effects of temperature and precipitation on runoff and sediment yield are particularly conspicuous (Langbein and Schumm, 1958; Knox, 1984). In such areas, rather modest changes in mean annual precipitation (i.e., $10 \%$ ) and temperature (i.e., $2^{\circ} \mathrm{C}$ ) can result in dramatic changes in mean annual sediment yield to valley settings in particular (Knox, 1984). Therefore, periods of warm and dry climate are likely to be associated with episodes of eolian, fluvial, and slopewash aggradation as hillslopes and uplands are stripped of vegetation and sediment is eroded, transported, and redeposited. On the other hand, periods of cool and moist climate are likely to result in landscape stability and soil formation. Under these conditions, sediment yield from slope runoff and wind deflation is reduced, and streams, denied sediments, begin to downcut. 
This model formed the conceptual framework for the interpretation of depositional and climatic environments associated with the late Pleistocene/Holocene-age Oahe Formation in North Dakota (Clayton and others, 1976). Studies in the badlands of western North Dakota and elsewhere have since verified the usefulness of this pattern, but have also identified the importance of local geomorphic conditions and, hence, accentuate the need to consider scale when interpreting soil, climatic, and landform data (Kuehn, 1995).

On the scale of physiographic sections, subsections, and regions, the basic climate/ landscape model of Knox (1984), Langbein and Schumm (1958), Clayton and others (1976), and others holds great promise. Problems arise at the local level or in attempting to correlate patterns noticeable at a number of small, isolated localities scattered over a large region. The following discussion highlights some of the basic concepts of the large-scale model in light of the basic goals of the project.

In general, episodes of alluvial aggradation, as represented by discrete accumulations of floodplain and former floodplain sediments at various elevations and ages, suggest that warm and dry conditions prevailed or were at least more prevalent during the aggradational process. Episodes of valley downcutting suggest the opposite, that is, that cool and moist conditions prevailed during periods of alluvial degradation. The aggradation and degradation of windblown sediments (i.e., eolian or loess deposits) in western North Dakota appear to follow this same basic pattern (Clayton and others, 1976; Kuehn, 1995).

Paleosols represent periods of landscape stability. Landscape stability can result from a change in 1) climate, 2) local geomorphic conditions, and/or 3) other factors such as tectonics, eustatic activity, biologic activity, cultural activity, and fire. Climate is suspected as a causal factor behind paleosol formation when 1) synchronous soils are widespread and correlated beyond individual localities or drainage basins, 2) soil formation is occurring at multiple places at the same time, or 3) stable carbon isotope and other proxy sources indicate that soils are associated with episodes of cool-moist climate.

In western North Dakota, these climate, soil, and geomorphic relationships strongly suggest that investigations must focus on the analysis of data at all scales, including 1) intrasite or small scale (i.e., within a single stratigraphic section), 2) intersite or medium scale (i.e., between different stratigraphic sections within the same subregion), and 3) large scale (i.e., between subregions, regions, and provinces). The types of data to be considered in such multiscaled investigations include 1) geomorphic setting, 2) geomorphic history, 3) soils (including thickness, level of development, and correlation), 4) unit contacts and general stratigraphy, 5) evidence of geological unconformities, 6) textural changes and changes in depositional environments, and 7) proxy climatic data, such as stable carbon, pollen, phytoliths, diatoms, and snails.

In order to draw meaningful inferences concerning the relationships between climate, geomorphology, and soils, research must initially focus at the intrasite, or locality, level, where geologic sections are measured and which represents the main emphasis of this project. Subsequently, however, data concerning intersite correlations and regional phenomena must be incorporated to weigh the significance of local results and interpretation. The ultimate goal of this 
project is to validate the premise that short-term cycle patterns can be meaningfully interpreted in geomorphically dynamic terrains to establish regional and, hopefully, global context.

\subsubsection{Summary of Paleosol Research}

Research completed to date by Hartman and others $(1997,1998)$ and Hartman and Kuehn (1999) suggests the potential for significant use of paleosols in sensitive semiarid terrains. Concerning short-term cycles, we have learned that late Holocene sediments in the badlands of Theodore Roosevelt National Park, Billings County, and in the prairie settings of the Knife River Indian Village National Historic Site, Mercer County, and along the north shore of Lake Sakakawea (Missouri River), McLean County, preserve a record of numerous paleosols buried by alluvial deposits. Along the headwaters of Knutson Creek in Theodore Roosevelt National Park, $\mathrm{Ab}$ horizons occur in minor sections $(<1.6 \mathrm{~m})$ with as many as ten paleosols. Although these have not been dated directly, a date from a nearby section suggests formation of the paleosols over the last 1430 years. The Knife River Elbee Bluff Locality contains eight Ab horizons in a 2.4-m section, the middle portion of which has five thin, evenly spaced paleosols from about 2000 to 2974 years before present (BP). The Lake Sakakawea Douglas Creek Locality consists of a stacked, apparently conformable sequence of $15 \mathrm{Ab}$ horizons in a $2.8 \mathrm{-m}$ section that can be traced laterally across a small paleovalley. The occurrence of paleosols at this locality can be interpreted over a span of 2655 years ( \pm analytical error). Landform instability may have resulted in alluvial deposition on average about once every 170 to 180 years.

The paleosol record preserved at all three localities indicates that soils seem to have been the result of relatively stable environments interrupted by brief episodes of burial every 140 to 200 years. The regularity of these burial events may stand as possible proxy indicators of minor climatic variation on an otherwise general record of climate stability. Stable carbon studies of these paleosols indicate generally cool and moist conditions $\left(-22.6 \pm 0.6 \delta^{13} \mathrm{C}_{\mathrm{PDB}} \% o\right)$, except for those forming about 2585 years BP (Douglas Creek) to at least 2165 years BP (Elbee Bluff), during which warmer and drier conditions $\left(-20.0 \pm 0.4 \delta^{13} \mathrm{C}_{\mathrm{PDB}} \%\right.$ o ) more likely prevailed.

\subsection{SCOPE OF WORK: STUDY EXAMPLES OF METHODS AND RESULTS}

This project represents an analysis of literature on climate change. A large number of papers on climate change issues were examined. Particular attention was given to methods that provide a means to interpret climate change patterns, cycles, or trends. Although the project focused on the recent past (Holocene), methods and interpretations that concerned major shifts or variability in the Earth's climate were also considered. As mentioned, the general absence of geological constraints in climate models does not indicate that climate has not changed significantly in the past, but that it is difficult to derive transform functions directly applicable to the temporal scale (i.e., short-term phenomena) that is of interest to the public. Examination of evidence of changes in the biotic and physical histories preserved in the sediment or rock record extends the limited historical record. Evidence of biotic change includes data derived from palynomorphs, diatoms, phytoliths, ostracodes, mollusks, and mosses. Evidence of climate-based changes can also be 
found in the physical properties of sediments such as changes in color, texture, mineralogy, trace metals, varve layering, pedogenic carbonate geochemistry, and stable carbon and oxygen isotopes.

The key element in interpreting these changes is our ability to construct high-resolution time scales to determine rate and, possibly, extent of climate change. Research on these topics includes radioactive isotopic geochronometers, paleomagnetic reversal stratigraphy, dendrochronology, varve time scales, and thermoluminescence.

\section{A. Palynomorphs}

A.1. Baker, R.G., Maher, L.J., Chumbley, C.A., and Van Zant, K.L., 1992, Patterns of Holocene environmental change in the midwestern United States: Quaternary Research, v. 37 , p. $379-389$.

Summary. The movement of the prairie ecozone boundary during the Holocene was studied from north-central Iowa to southeast Wisconsin using pollen assemblages collected from four locations. The collection sites included Clear Lake, Iowa; Roberts Creek, Iowa; Devils Lake, Wisconsin; and Lima Bog, Wisconsin. These sites record climate from 8000 to $3000 \mathrm{yr}$ BP.

In summary:

[f]rom the northern Great Plains east as far as south-central Minnesota and central Iowa, the sequence of vegetational changes resembles those at Clear Lake: Prairie elements appeared as early as about $9000 \mathrm{yr} \mathrm{BP}$ and were at their peak from 7500 to about 4000 yr BP. During this time of maximum aridity in these areas, moisture levels were at their peak and mesic forest was present along Roberts Creek and at the Wisconsin sites (Figure 5). Prairie invaded eastern Iowa only after $5500 \mathrm{yr}$ BP, at the same time that xeric forest replaced mesic forest in southern Wisconsin (p. 386).

Conclusion. This project is useful in that it traces the advance/retreat of prairie across several different sites. However, it would be a better project if the interpretation were not limited to only pollen data.

Keywords: Palynomorph analysis

A.2. Sauchyn, M.A., and Sauchyn, D.J., 1991, A continuous record of Holocene pollen from Harris Lake, southwestern Saskatchewan, Canada: Palaeogeography, Palaeoclimatology, Palaeoecology, v. 88, p. 13-23.

Background. The northern Great Plains study area of Harris Lake is located on the west block of the Cypress Hills region of southwestern Saskatchewan and southeastern Alberta. It is at an elevation of $1310 \mathrm{~m}$ in Saskatchewan and $1465 \mathrm{~m}$ in Alberta. Harris Lake was formed in a glacial meltwater channel approximately 12,000 yr BP. The lake has a surface area of 9 ha $\left(0.09 \mathrm{~km}^{2}\right)$ and a maximum depth of $1.5 \mathrm{~m}$. 
Analysis of texture and structure indicates a low-energy environment with stable lake levels since its initial formation, the only exception to this being higher sedimentation rates during the Altithermal. The mean sedimentation rate was determined to be $1.06 \mathrm{~mm} / \mathrm{yr}$. This was further divided into $1.7 \mathrm{~mm} / \mathrm{yr}$ from 3450 to $5120 \mathrm{yr} \mathrm{BP}$ and $0.28 \mathrm{~mm} / \mathrm{yr}$ from $1470 \mathrm{yr}$ BP to the present.

The major climate indicator studied at this site is pollen. Chronologic control at this site was achieved through radiocarbon dating and the identification of the Mazama ash (6800 yr BP). The first ${ }^{14} \mathrm{C}$ date of $9120 \pm 250 \mathrm{yr} \mathrm{BP}$ was obtained from the base of the 9.6-m core. Radiocarbon dates of plant macrofossils were taken at three other depths. Pollen samples were taken at 8-cm intervals along this core. Pollen analyses were divided into five zones, the ages of which were interpolated from dating methods previously mentioned.

Zone I represents 9120-7700 yr BP. During this period, "the tree-herb ratio is intermediate compared to the other zones; Populus is the main arboreal taxon and Pinus and Picea are at lower levels in this zone than anywhere else in the profile" (p. 17). This assemblage represents a Populus-grassland-shrub complex. The vegetation is transitioning into prairie. Zone II encompasses the period between 7700 and $5000 \mathrm{yr} \mathrm{BP}$ and is considered to represent the Altithermal. At the Zone I-Zone II boundary, Populus and Araceae pollen percentages decline drastically and Pinus increases. "Trees and aquatics are at minimum levels, while herbs are at maximum" (p. 17). Plant taxa indicative of dry, saline, or disturbed areas are at their maximum of this profile in this zone. Overall, "this vegetation indicates the driest conditions in the profile" (p. 19). Zone III ranges from 5000 to $4500 \mathrm{yr} \mathrm{BP}$ and is interpreted to represent conditions transitional between the [A]ltithermal of Zone II and the climatic deterioration evident in Zone IV. Levels of Populus and Chenopodiaceae-Amaranthaceae decrease, while Pinus Picea, Sphagnum, Typha, and Betula increase. Also, Urticaceae levels are at their maximum, indicating "more stream bank and moist woodlands habitat. These vegetation changes suggest the onset of cooler and wetter conditions (p. 19). Zone IV bounds the period from 4500 to $3200 \mathrm{yr}$ BP. The changes that occur here "suggest that forest cover, in particular spruce forest, increased substantially and rapidly after the [A]ltihermal. Pinus levels of 25-30\% indicate that pine was definitely in the Cypress Hills at this time. Wetter conditions also are indicated by the increase in aquatic pollen" (p. 19). Zone V includes from $3200 \mathrm{yr}$ BP to the present. Pinus pollen increases substantially, while Gramineae, Cyperaceae, Chenopodiaceae-Amaranthaceae, Ambrosiinae, Caryophyllaceae, and herbs decrease only slightly. "There has been little vegetation, and by inference, climatic change over the last 3200 yrs in the Cypress Hills. The present mosaic of grassland, Piceae forest, Populus tremuloides forest, Pinus contorta forest, and wetland vegetation in the Cypress Hills is reflected in the pollen profile of this zone" (p. 19).

Summary. The Altithermal is represented in the section by the time period of $7700-5000 \mathrm{yr}$ BP. Maximum warmth and aridity occurred around 7700 to $6800 \mathrm{yr}$ BP. A cooling trend began approximately $5000 \mathrm{yr}$ BP. Finally, the modern vegetation assemblage developed around $3200 \mathrm{yr}$ BP.

The study of Harris Lake includes a continuous record of the Holocene for the northern Great Plains. This record has decent chronological control, although more radiocarbon dates derived through accelerator mass spectrometer (AMS) methods would benefit the interpretations. 
The data from this location appear to support data from other studies in the region in both type of climate fluctuation and the timing of these events.

Conclusion. This well done but traditional pollen work could serve as an important reference standard if additional geochemical and radiometric analyses were conducted. The temporal span of the stratigraphic section provides an opportunity to correlate other similar studies.

Keywords: Palynomorph analysis

\section{B. Phytoliths}

B.1. Fredlund, G.G., and Tieszen, L.L., 1997, Phytolith and carbon isotope evidence for late Quaternary vegetation and climate change in the southern Black Hills, South Dakota: Quaternary Research, v. 47, p. 206-217.

Background. Identification of phytolith assemblages and analysis of stable carbon isotopes were coupled to provide a more complete interpretation of climate change in the Wind Cave National Park of the Black Hills, South Dakota. Paleosols were important to this study in defining periods of landscape stability. Following an early period of instability between 8000 and $4500 \mathrm{yr}$ $\mathrm{BP}$, one ancient soil formed across much of the landscape, recording a significant period of landscape stability from ca. 4500 to $3600 \mathrm{yr}$ BP. This soil was abruptly buried by sediments from a second period of landscape instability from about 3600 to $1200 \mathrm{yr}$ BP (p. 210).

The phytolith and stable carbon data indicate that the largest change in climate occurred between 11,000 and $9000 \mathrm{yr}$ BP. During this time, $\delta^{13} \mathrm{C}$ values rose from $-24.01 \%$ o to $-20.01 \%$, indicating a transition from $\mathrm{C}_{3}$ vegetation to a $\mathrm{C}_{3}-\mathrm{C}_{4}$ mixture. At approximately 8000 years $\mathrm{BP}$, the "erosional unconformity suggests xeric climatic conditions" (p. 215). Following this, the $\delta^{13} \mathrm{C}$ values were typically $-19.01 \%$ o to $-21 . \%$, with the maximum being $-15.81 \%$ o. These values represent dominance by $\mathrm{C}_{4}$ vegetation.

Summary. In the Wind Cave area, the climate was cool and moist from 11,000 to $9000 \mathrm{yr}$ BP. This was followed by a transition to more xeric conditions, which continued into the late Holocene.

Conclusion. The phytolith data in this study are used more to support the $\delta^{13} \mathrm{C}$ values than to identify climatic changes. However, their use does help to create a fuller view of the environmental change during the Holocene.

Keywords: Phytoliths, stable carbon, paleosols 


\section{Diatoms}

C.1. Brugam, R.B., 1980, Postglacial diatom stratigraphy of Kirchner Marsh, Minnesota: Quaternary Research, v. 13, p. 133-146.

Summary. The assemblages of diatoms found were compared by cluster analysis with modern assemblages identified at 159 lakes in Minnesota and Labrador. The period of time encompassed by the Kirchner Marsh record, $25 \mathrm{mi}$ south of Minneapolis, is from 13,000 to $5500 \mathrm{yr}$ BP. The ages applied to different positions along the core used for this study are based on correlations of pollen stratigraphy between this core (K-7) and a previously dated core (K-1). One problem with the use of diatom assemblages, as stated by the authors, is that there is no a priori reason "why diatoms should be related in a continuous, linear manner to environmental variables. The true relationships may be nonlinear or involve discontinuities or threshold effects" (p. 141). It is for this reason that cluster analysis was used rather than multiple linear regression techniques.

Pollen Zone A contains no planktic species preserved, while epipelic species dominate. This could indicate a lake of any depth, but clarity is required to support the dominant species if the lake was of great depth. Zone A-b (13,000-10,200 yr BP) reflects an increase in productivity, clear water, and relatively deep water. Zone B (10,200-9500 yr BP) provides little definitive information in that the assemblages identified here do not have a modern analog. Beginning at $9500 \mathrm{yr}$ BP, a short period of eutrophication occurred. Then, "both the rise in spicules and the dominance of epiphytic species indicate shallowing beginning the middle of zone C-a" (7500-5500 yr BP) (p. 144). Any assemblages younger than this are difficult to interpret in terms of water depth in that they do not match any modern lake assemblages.

Conclusion. The timing of events recorded at this site is not made clear in this paper except for comments made in the abstract. The paper would have been more useful if a discussion of the ages of pollen zones had been included. Otherwise, this study applies an interesting method, trying to directly equate the subfossil climate record with modern analogs, drawing from previous studies to make a more informed interpretation of climate change.

C.2. Laird, K.R., Fritz, S.C., Grimm, E.C., and Mueller, P.G., 1996, Century-scale paleoclimatic reconstruction from Moon Lake, a closed-basin lake in the northern Great Plains:

Limnology and Oceanography, v. 41, no. 5, p. 890-902.

Background. Moon Lake is located in the northern Great Plains Region, Barnes County, North Dakota. The features of this lake that make it an excellent candidate for paleoclimate reconstruction studies include "a small catchment, a topographically closed basin, a continuous Holocene sediment record, and a hydrological setting in which groundwater recharge is primarily driven by precipitation."

An 11.2-m core was taken from the deepest part of the basin and was found to have a basal date of 11,800 yr BP. Diatom and pollen were analyzed at 4-8-cm intervals through the core, which resulted in a temporal spacing of 50-200 years. AMS dating of charcoal flakes provided ages of individual sections of the core. Of the samples collected for identification of diatoms and 
pollen assemblages, nine from the period 4700-2200 yr BP contained less than 50 specimens, and these were eliminated from the data set. Also, diatom preservation at the base of the core was limited and therefore did not provide much information.

Summary. A century-scale analysis of the Holocene diatom record indicated four major hydrological periods: 1) an early Holocene transition from an open lake of low salinity $(<2 \mathrm{~g} / \mathrm{L})$ to a closed saline system (salinity $>20 \mathrm{~g} / \mathrm{L}$ ) between 10,000 and $7300 \mathrm{yr} \mathrm{BP}$, which corresponds to the transition from spruce forest to deciduous parkland to prairie and suggests a major shift from wet to dry climate; 2) a mid-Holocene period (7300-4700 yr BP) of high salinity, indicating low effective moisture; 3) a transitional period from 4700 to $2200 \mathrm{yr}$ BP of high salinity, characterized by poor diatom preservation; and 4) a late Holocene period of variable lower salinity ( $<2200 \mathrm{yr}$ $\mathrm{BP}$ ), indicative of fluctuations in effective moisture.

The authors believe that during the early Holocene, Moon Lake was a freshwater lake with an outlet. During this freshwater stage, the lake would have had a larger surface area and volume than at present. The shift from fresh to saline conditions occurred in two stages: first, a gradual transition between $\sim 10,000$ and $8100 \mathrm{yr}$ BP from $\sim 1$ to $4 \mathrm{~g} / \mathrm{L}$ (Period 1a); followed by a more rapid transition from 2 to $>20 \mathrm{~g} / \mathrm{L}$, culminating by $\sim 7300 \mathrm{yr}$ BP (Period $1 \mathrm{~b}$ ).

These interpretations are further supported by pollen studies, which indicate vegetation at 10,300 yr BP was dominated by spruce (Picea). This was replaced by a deciduous forest dominated by elm (Ulmus) and oak (Quercus). The presence of elm is important because it indicates a poorly drained soil. At $8000 \mathrm{yr}$ BP, elm began to be replaced by Ambrosia, and by $\sim 7000$ yr BP, oak disappeared and Ruppia appeared. Following this transition, at about $7300 \mathrm{yr}$ $\mathrm{BP}$, salinity rapidly increased, indicating lower water levels. At $\sim 6600-6300 \mathrm{yr} \mathrm{BP}$, rapid deposition of sediment occurred. Finally, although high salinity levels have dominated the system, small fluctuations in lake salinity have occurred from 2200 to $750 \mathrm{yr}$ BP, while from 7500 to 100 yr BP, large-scale fluctuations have occurred.

Conclusion. The Moon Lake study is important, because climate change can be interpreted at century-scale intervals. The validity of the authors' approach was proven by comparing their results for the past 200 years with recorded information from nearby weather stations. Further, this study is important because it relies on integrating two types of analysis, palynology and diatoms, to interpret the paleoclimate fluctuations. It is unfortunate that stable carbon studies could not be included in the sampling procedure.

Keywords: Salinity, ostracodes, diatoms, pollen, AMS radiocarbon dating

\section{Ostracodes/Diatoms}

D.1. Fritz, S.C., Engstrom, D.R., and Haskell, B.J., 1994, "Little Ice Age" aridity in the North American Great Plains - a high-resolution reconstruction of salinity fluctuations from Devils Lake, North Dakota, USA: The Holocene, v. 4, no. 1, p. 69-73. 
Background. A lake sediment core ( $84 \mathrm{~cm}$ in length) was obtained from Creel Bay, Devils Lake, North Dakota. The core was analyzed for diatoms, bulk carbonate geochemistry, and trace element composition of ostracode shells. The combination of the results of these methods was used to interpret past salinity fluctuations in the lake, thus indicating periods of climatic change. Chronological control on the variations is based on ${ }^{210} \mathrm{~Pb}$ dating.

Sediment accumulation rates for the dated intervals of the core range from 50 to $150 \mathrm{mg}$ $\mathrm{cm}^{-2} \mathrm{yr}^{-1}$ and show no systematic increase following European settlement in the 1880s (Jacobson and Engstrom, 1989). The results of ${ }^{210} \mathrm{~Pb}$ dating suggest that each sediment sample represents 1 to 5 years of accumulation in the upper part of the core and above 10-15 years near the base of the sequence (p. 700).

The diatom-inferred salinity reconstruction suggests that Devils Lake was saline (salinity $>31$ ) throughout the last 500 years, except during the last decade. Prior to AD 1850, mean salinity was typically high ( $>20 \%$ ), with only three periods when salinity was somewhat lower (10\%o-20\%o), in approximately the AD 1580s, 1640s, and 1720s. The data suggest a shift in lake water chemistry about AD 1850, with lower mean salinities 10\%o-20\%o) and less extreme fluctuations through the 1940s. After 1950 inferred salinity gradually declined, parallel with modern records of measured salinity (Fritz, 1990) (p. 71).

The salinity variations indicated by diatom analysis are supported by the trace element composition of ostracode shells and by bulk carbonate geochemistry. One exception to this is "a period about $\mathrm{AD} 1810$ when ostracode $\mathrm{Mg} / \mathrm{Ca}$ ratios suggest more dilute conditions during an interval when diatom-inferred salinity is relatively stable" (p. 71).

Summary. The Devils Lake region was characterized by an arid climate and drought conditions from the 1500s until the mid-1800s. After this period, there was "an increase in the frequency of moist intervals as compared to previous centuries" (p. 71). Modern records report a drought from the 1930s to 1940s followed by increased rain in the 1960s to 1980s. The most recent low salinities "are unparalleled during the rest of the 500-year record" (p. 72).

Conclusion. The integration of core data in this study serves as a model for future studies that can employ similar core and microfossil materials.

Keywords: Diatoms, ostracodes, carbonate geochemistry, ${ }^{210} \mathrm{~Pb}$ dating, limnology

D.2. Haskell, B.J., Engstrom, D.R., and Fritz, S.C., 1996, Late Quaternary paleohydrology in the North American Great Plains inferred from the geochemistry of endogenic carbonate and fossil Ostracodes from Devils Lake, North Dakota, USA: Palaeogeography, Palaeoclimatology, Palaeoecology, v. 124, p. 179-193.

Background. Devils Lake, in eastern North Dakota, is in a closed drainage basin of about $9800 \mathrm{~km}^{2}$. The lake was formed in a depression resulting from glacial thrusting of the underlying Cretaceous shale. This study focuses on the use of ostracodes and bulk carbonate geochemistry as lake water chemistry recorders. The samples were obtained from a 24-m-long core taken in Creel 
Bay in an area where the water depth was $7.5 \mathrm{~m}$. "Diatom analyses (Fritz, et al., 1991) were performed on point samples, and the bulk-carbonate geochemistry samples integrated $2-\mathrm{cm}$ sections of core overlapping with the diatom samples. Ostracode samples came from $8-\mathrm{cm}$ sections adjacent to the diatom and bulk carbonate samples" (p. 80).

\section{Summary.}

Ostracode and bulk-carbonate data from the lowest part of the core representing $12-10.5$ k.y. suggest low salinity at this time, corroborating inferences from sedimentary diatom assemblages (Fritz, et al., 1991). Pollen and geochemical results indicate that the region was covered by spruce forest, with soil conditions that favored the leaching of iron and manganese into drainage waters entering the lake. During this period of cool/moist climate, a fresh and more extensive Devils Lake overflowed its now-abandoned spillway into the Sheyenne River (Aronow, 1957). Between 10.5 and 8 k.y. increases in the ostracode and bulk carbonate elemental ratios suggest the development of a hydrologically closed basin. This interpretation is supported by diatom-inferred salinity and pore-water concentration which indicate that maximum salinity of the lake occurred around $8 \mathrm{k} . \mathrm{y}$. The rapid change in climate is also indicated by the replacement of spruce pollen by prairie taxa (H.A. Jacobson, unpublished data).

After 8 k.y., there was an overall trend toward lower salinity, although this period was interspersed with large salinity fluctuations ... A particularly low salinity interval from 3.5-4.5 k.y. is apparent in the data (p. 189).

This was followed by a return to higher salinity levels. The magnitude of the salinity fluctuations was greater during the early Holocene than in the late Holocene. "The diatom record shows higher mean salinity values during the last $2.5 \mathrm{k} . \mathrm{y}$., but pore-water $\mathrm{Na}$ only shows high concentrations from 0.5-1.3 k.y. These data, coupled with a high-resolution record of the last 500 years (Fritz et al., 1994) suggest that the salinity of Devils Lake during the past 50 years has been considerably lower than it was throughout most of the Holocene (after 8.5 k.y.)" (p. 190).

In summary, between 10.5 k.y. and 8 k.y., salinity increased in the freshwater glacial lake. Major fluctuations in salinity occurred until 7.5 k.y. From this point until 4.5 k.y., fluctuations became less frequent and of smaller magnitude. The period from 4.5 to $3.5 \mathrm{k}$.y. was characterized by relatively fresh conditions. Following this period, small-scale fluctuations in salinity in the lake returned.

This study combines multiple sources of data to determine the magnitude and degree of salinity fluctuations in Devils Lake. It also used pollen resources to support that these fluctuations are the result of local climate variations. The authors note several reasons why some of the data do not correspond to other data. However, overall, the compilation of the analysis results shows that the majority of it seems to agree fairly well. 
salinity

Key Words: Limnology, palynology, diatoms, ostracodes, carbonate geochemistry,

\section{E. Eolian Deposition and Dune Migration}

E.1. Dean, W.E., Ahlbrandt, T.S., Anderson, R.Y., and Bradbury, J.P., 1996, Regional aridity in North America during the middle Holocene: The Holocene, v. 6, no. 2, p. 145-155.

Summary. This paper focuses on climatic variations from 8000 to 3800 in northwestern Minnesota as evidenced by active sand dune migration. Elk Lake and Lake Ann varved sediments provide excellent documentation of influx of eolian material. The variations in varve thicknesses are due mainly to input of eolian clastic material. Spectral analysis of varve thicknesses indicate "[t]he strongest periodicities . . . are for about 200 years, 40-50 years, and 20-25 years" (p. 149), which indicates that instability in eolian landforms was occurring during these intervals. The maximum eolian deposition at these locations occurred at 6000 calendar yr BP.

Conclusion. This paper is important in that it provides a reference to contrast other aridity studies, but would have been improved by placement of all of its data on a standard time scale.

Keywords: Varves, eolian, spectral analysis

E.2. Feng, Z., Johnson, W.C., Lu, Y., and Ward, P.A., 1991, Climatic signals from loess-soil sequences in the central Great Plains, USA: Palaeogeography, Palaeoclimatology, Palaeoecology, v. 110, p. 345-358.

Background. The late Quaternary eolian deposition of the Loveland and Peoria loesses and pedogenesis within these units are excellent examples of periods of landscape instability and stability in Nebraska and Kansas. This study focuses on these two deposits as well as the paleosols of the Gilman Canyon Formation. Thermoluminescence age determinations provided resolution of the timing of these events. "Four cycles of pedogenic carbonate formation occurred during Loveland time: after $416 \pm 35 \mathrm{ka}$, before $260 \pm 25 \mathrm{ka}$, around $193 \pm 22 \mathrm{ka}$ and before $92 \pm 7 \mathrm{ka"} \mathrm{(p.} \mathrm{355).} \mathrm{The} \mathrm{presence} \mathrm{of} \mathrm{pedogenic} \mathrm{carbonate} \mathrm{reflects} \mathrm{a} \mathrm{dry,} \mathrm{warm} \mathrm{climate.} \mathrm{The}$ Barton sand was deposited from 95 to $70 \mathrm{ka}$. "The magnetic susceptibility suggests that the slightly reddish eolian sand experienced multiple pedogenic impacts. It might have formed under relatively warm and probably fluctuating moisture conditions" (p. 355). The period of 70 to $35 \mathrm{ka}$ is recorded by a reddish pedocomplex that was deposited at a low rate and is strongly weathered. This soil was developed under stable conditions of a moderate climate. Conditions changed to moist and cool from 35 to $20 \mathrm{ka}$ as recorded by the Gilman canyon pedocomplex. Following this, the Peoria Loess was deposited rapidly under cold and dry conditions. From 10.5 to $8.5 \mathrm{ka}$, the Brady soil marked a period of system stability. This was covered by the deposition of the Bignell Loess (8.5 to $5.8 \mathrm{ka}$ ), which may mark the Altithermal (warm and dry).

Summary. Dry and warm climates existed after $416 \pm 35 \mathrm{ka}$, before $260 \pm 25 \mathrm{ka}$, around $193 \pm 22 \mathrm{ka}$, and before $92 \pm 7 \mathrm{ka}$. These periods were followed by warm conditions with fluctuating moisture levels from 90 to $70 \mathrm{ka}$, and a moderate climate prevailed from 70 to $35 \mathrm{ka}$. 
Subsequently, the climate became cool and moist until $20 \mathrm{ka}$. From 20 to $10.5 \mathrm{ka}$, conditions remained cool, but aridity increased. From 10.5 to $8.5 \mathrm{ka}$, landscape stability returned, and this was followed by a warm dry period from 8.5 to $5.8 \mathrm{ka}$.

Conclusion. Studies of this type provide useful information on the nature of climate change over a broad period of time, but have limited value for finely resolved interpretations or correlation.

Keywords: Thermoluminescence, loess pedogenic carbonate, magnetic susceptibility

E.3. Forman, S.L, Goetz, A.F.H., and Yuhas, R.H., 1992, Large-scale stabilized dunes on the high plains of Colorado-Understanding the landscape response to Holocene climates with the aid of images from space: Geology, v. 20, p. 145-148.

Background. This study focuses on the movement of large-scale, parabolic dunes (some $>10 \mathrm{~km}$ ) located in eastern Colorado. Such dunes are activated during arid periods. The record of dune movement was based on Landsat Thematic Mapper images, with radiometric dates of periods of movement based on aquatic pulmonate snails and buried soil horizons sampled from contact zones. "Field studies indicate that these landforms are sensitive to climate change and that four periods of dune reactivation have occurred in the Holocene and, most recently, during the last millennium" (p. 148). These periods are dated to have occurred from 9500 to $5500 \mathrm{yr} \mathrm{BP}$, from 5500 to $>4800 \mathrm{yr} \mathrm{BP}$, from 4800 to $>1000 \mathrm{yr} \mathrm{BP}$, and $<100 \mathrm{yr} \mathrm{BP}$. These dunes are currently covered with short-grass vegetation and thus are stable.

Summary. This study utilized a variety of technologies and also some basic fieldwork to provide information for over a 10,000-year period. Also, the authors were very thorough in describing the hypotheses behind their methods and interpretation.

Conclusion. One shortfall of the study, however, is that the ages lacked sufficient precision in dating activation periods to allow for little, if any, time over which stable periods could be established.

Keywords: Landsat Thematic Mapper, radiometric dating, eolian, pulmonates, paleosols

\section{F. Peat Lands}

F.1. Glaser, P.H., Bennett, P.C., Siegel, D.I., and Romanowicz, E.A., 1996, Palaeo-reversals in groundwater flow and peatland development at Lost River, Minnesota, USA: The Holocene, v. 6, no. 4, p. 413-421.

Background. The flow of groundwater in a peat bog/fen at Lost River in the Glacial Lake Agassiz peat lands, northwestern Minnesota, was studied to determine the aridity of the region during the past 4000 years. "The record of groundwater flow was reconstructed by stratigraphic studies that utilized both botanical indicators of the surface-water chemistry, and mineral indicators of the pore-water chemistry and chemical weathering regime" (p. 413). 
Summary. Between 2000 and 1200 yr BP, two peat mounds formed within this peat land that resulted in a change in the local hydrology, which up to this point was a groundwater discharge zone. The formation of the peat mounds resulted in recharge cells forming and the "establishment of two raised bogs dominated by Sphagnum" (p. 418). By $1200 \mathrm{yr}$ BP, the region had reverted to a discharge zone. One of the bogs became a spring fen (discharge), while the amount of discharge did not affect the surface of the larger bog (recharge). Model simulations for similar situations suggest that "the origin of the spring fen at Lost River may therefore represent a time when extreme droughts first became common within this region" (p. 419). This study indicates a generally moist climate from 4000 until 1200 yr BP. After 1200 BP, aridity occurred periodically.

Conclusion. This is an interesting and novel approach to interpreting climate change. Although it is limited in that it is applicable only to bog/fen areas, it proved to be a sensitive indicator of change.

Keywords: Wetlands, hydrology, chemical weathering, Sphagnum

\subsection{CONCLUSIONS}

Short-term cycle research calls for integrated geological, paleontological/biological, and analytical research methods. The concatenation of research expertise brings together methods that provide for precise temporal frameworks, either as single points that can be tied to larger scenarios or as closely spaced control points where accurate interpolation is possible. Many of the studies done prior to the 1990s provide only a general framework, with limited temporal resolution, for interpreting a constantly changing climate. Although many useful early studies showing climate trends or patterns have been conducted, few have the power to resolve the minor variations in climate that have a significant impact on culture stability without actually constituting a major climate shift (e.g., changes in temperature or precipitation that result in drought or flooding).

The geologic record of the earth shows that natural climate variations reach extremes far beyond the local concerns of today's societies. However, climate variation or cycles influenced by human culture may produce unforeseen consequences. As a philosophical point, I do not believe we understand, other than in a general way, where we are on the earth's present climate curve. Maybe more to the point is where specific regions of the world are on this curve. What may devastate Manhattan and Texas may be a boon to North Dakota. The shifting of climate patterns on the globe thus may produce both positive and negative consequences, depending on the economy and culture of an area.

Research works that establish the rapidity with which climate change can produce consequences may have significant value even if cycles or long-term trends cannot be established. Works noted above that include the analysis of the biological and physical properties of a stratigraphic section (e.g., lake core) can serve as proxy frameworks for climate change by ultimately interpreting the wetting and drying of an area. Thus studies that include evidence of 
increasing salinity as an indicator of drying should also include other stable isotope and geochemical data, the trends of which can then be recognized as potentially indicative of specific climate change.

Paleosol studies in midcontinental areas of generally stable, semiarid climate, where wetting and drying of sediment drastically affect alluvial and eolian processes, may be good indicators of rapid climate change. The pros and cons of such work have been noted elsewhere (Hartman and others, 1998), but such studies under good conditions, correlated with lake basin studies, may provide for an intraregional approach to climate variation and cycles.

As a working idea to be further investigated, I propose that "climate sections" be established to serve as a standard of reference for a climate history for a region. This idea is somewhat analogous to concepts of use established in stratigraphy (North American Commission on Stratigraphic Nomenclature, 1983; Remane and others, 1996). In stratigraphic studies, stratigraphic sections are chosen that represent type, or reference, examples of a particular formation, range of fossil occurrence, or time boundary. Means of correlation from one area to another are based on whatever appropriate criteria are available, and with sufficient study, events in space and time can be placed into coherent histories.

Similarly, climate sections can be established on the basis of criteria that provide the optimum conditions for spatial and temporal correlation within a region. As a result, the climate history can be established and honed to greater accuracy with increasing study and technological advances. Working with these climate sections may also provide an ideal opportunity to integrate cultural data derived from anthropological studies. As culture and climate are highly correlated, a convincing history of climate change may well be possible.

\subsection{REFERENCES}

Baker, R.G., Maher, L.J., Chumbley, C.A., and Van Zant, K.L, 1992, Patterns of Holocene environmental change in the midwestern United States: Quaternary Research, v. 37, p. 379-389.

Bradbury, J.P., Dean, W.E., and Anderson, R.Y., 1993, Holocene climatic and limnologic history of the north-central United States as recorded in the varved sediments of Elk Lake, Minnesota - a synthesis: Geological Society of America Special Paper 276, p. 309-328.

Brugam, R.B., 1980, Postglacial diatom stratigraphy of Kirchner Marsh, Minnesota: Quaternary Research, v. 13, p. 133-146.

Bryan, R., and Yair, A., 1982, Perspectives on studies of badland geomorphology, in Bryan, R., and Yair, A., eds., Badland geomorphology and piping: Norwich, England, Geo Books, p. 1-12.

Butzer, K.W., 1976, Geomorphology from the earth: New York, Harper and Row. 
Clayton, L.S., Moran, S.R., and Bickley, W.B., Jr., 1976, Stratigraphy, origin, and climatic implications of late Quaternary upland site in North Dakota: North Dakota Geological Survey Miscellaneous Series 54, 15 p.

Dean, W.E., Ahlbrandt, T.S., Anderson, R.Y., and Bradbury, J.P., 1996, Regional aridity in North America during the middle Holocene: The Holocene, v. 6, no. 2, p. 145-155.

Derbyshire, E., 1976, Geomorphology and climate: London, John Wiley and Sons.

Feng, Z., Johnson, W.C., Lu, Y., and Ward, P.A., 1991, Climatic signals from loess-soil sequences in the central Great Plains, USA: Palaeogeography, Palaeoclimatology, Palaeoecology, v. 110, p. 345-358.

Folland, C.K., Karl, T.R., and Vinnikov, K.Y., 1991, Observed climate variations and change, in Houghton, J.T., Jenkins, G.J., and Ephraums, J.J., eds., Climate change-the IPCC scientific assessment: Cambridge, Cambridge University Press, p. 195-238.

Forman, S.L, Goetz, A.F.H., and Yuhas, R.H., 1992, Large-scale stabilized dunes on the High Plains of Colorado- understanding the landscape response to Holocene climates with the aid of images from space: Geology, v. 20, p. 145-148.

Fredlund, G.G., and Tieszen, L.L., 1997, Phytolith and carbon isotope evidence for late Quaternary vegetation and climate change in the southern Black Hills, South Dakota: Quaternary Research, v. 47, p. 206-217.

Fritz, S.C., 1990, Twentieth-century salinity and water-level fluctuations in Devils Lake, North Dakota - test of a diatom-based transfer function: Limnology and Oceanography, v. 35, no. 9, p. 1771-1781.

Fritz, S.C., Juggins, S., Battarbee, R.W., and Engstrom, D.R., 1991, Reconstruction of past changes in salinity and climate using a diatom-based transfer function: Nature, v. 352, p. 706-708.

Fritz, S.C., Engstrom, D.R., Haskell, B.J., 1994, "Little Ice Age" aridity in the North American Great Plains - a high-resolution reconstruction of salinity fluctuations from Devils Lake, North Dakota, USA: The Holocene, v. 4, no. 1, p. 69-73.

Glaser, P.H., Bennett, P.C., Siegel, D.I., and Romanowicz, E.A., 1996, Palaeo-reversals in groundwater flow and peatland development at Lost River, Minnesota, USA: The Holocene, v. 6, no. 4, p. 413-421.

Hartman, J.H., Beck, D.L., Kuehn, D.D., Reid, J.R., and Reiten, J., 1997, Paleosols as proxy data for climate change-interpreting Holocene deposits in the badlands and prairies of western North Dakota: Geological Society of America Abstracts with Programs, v. 29, no. 6, p. A-34. 
Hartman, J.H., Beck, D.L., Kuehn, D.D., Reid, J.R., and Reiten, J., 1998, Final report to the Electric Power Research Institute: Holocene cyclicity in western North Dakota—climate change interpreted from fluctuations in alluvial sedimentation: Grand Forks, University of North Dakota Energy \& Environmental Research Center.

Hartman, J.H., and Kuehn, D.D., 1999, Holocene climate change interpreted from fluctuations in alluvial sedimentation in western North Dakota, in Steadman, E., and Todhunter, P., eds., An update on the flooding of the Red River of the North and Devils Lake Basins, North Dakota-developing a comprehensive water strategy: North Dakota Academy of Science, Proceedings, v. 53, p. 62-71.

Haskell, B.J., Engstrom, D.R., and Fritz, S.C., 1996, Late Quaternary paleohydrology in the North American Great Plains inferred from the geochemistry of endogenic carbonate and fossil ostracodes from Devils Lake, North Dakota, USA: Palaeogeography, Palaeoclimatology, Palaeoecology, v. 124, p. 179-193.

Jacobson, H.A., and Engstrom, D.R., 1989, Resolving the chronology of recent lake sedimentsan example from Devils Lake, North Dakota: Journal of Palaeolimnology, v. 2, p. 81-98.

Knox, J.C., 1984, Fluvial responses to small scale climatic changes in Costa, J.E., and Fleisher, P.J., eds., Developments and applications in geomorphology: Berlin, Springer-Verlag, p. 318-342.

Kuehn, D.D., 1995, The geoarchaeology of the Little Missouri Badlands - the Late Quaternary stratigraphic and paleoenvironmental context of the archaeological record [Ph.D. Dissertation]: College Station, Texas A\&M University.

Laird, K.R., Fritz, S.C., Grimm, E.C., and Mueller, P.G., 1996, Century-scale paleoclimatic reconstruction from Moon Lake, a closed-basin lake in the northern Great Plains: Limnology and Oceanography, v. 41, no. 5, p. 890-902.

Langbein, W.B., and Schumm, S.A., 1958, Yield of sediment in relation to mean annual precipitation: Transactions of the American Geophysical Union, v. 39, p. 1076-1084.

McAndrews, J.H., 1966, Postglacial history of prairie, savanna, and forest in northwestern Minnesota: The Torrey Botanical Club Memoirs, v. 22, no. 2, 72 p., 6 pls.

North American Commission on Stratigraphic Nomenclature, 1983, North American stratigraphic code: American Association of Petroleum Geologists Bulletin, v. 67, no. 5, p. 841-875.

Remane, J., Bassett, M.G., Cowie, J.W., Gohrbandt, K.H., Lane, H.R., Michelsen, O., and Naiwen, W., 1996, Revised guidelines for the establishment of global chronostratigraphic standards by the International Commission on Stratigraphy (ICS): Episodes, v. 19, no. 3. 
Sauchyn, M.A., and Sauchyn, D.J., 1991, A continuous record of Holocene pollen from Harris Lake, southwestern Saskatchewan, Canada: Palaeogeography, Palaeoclimatology, Palaeoecology, v. 88, p. 13-23.

Schumm, S.A., 1973, Geomorphic thresholds and complex response of drainage systems, in Morisawa, M., ed., Fluvial geomorphology: Binghampton, State University of New York, Publications in Geomorphology, p. 299-310. 


\section{APPENDIX A}

\section{SELECTED CLIMATE PAPERS ORGANIZED BY TOPIC}




\section{SELECTED CLIMATE PAPERS ORGANIZED BY TOPIC}

The following list of topically organized references on climate change is not intended to be exhaustive, but to provide examples of current studies addressing research topics or interests.

\section{Climate Change Philosophy and Discussion}

Axelrod, D.I., 1992, What is an equable climate? [abstract]: Palaeogeography, Palaeoclimatology, Palaeoecology, v. 91, no. 1-2, p. 1-12.

Berger, A.R., 1998, Environmental change, geoindicators, and the autonomy of nature: GSA Today, v. 8, no. 1, p. 3-8.

Bloom, D.E., 1995, International public opinion on the environment: Science, v. 269, p. 354-356. Brown, K.S., 1999, Taking global warming to the people: Science, v. 283, p. 1440-1441.

Culotta, E., 1993, Is the geological past a key to the (near) future?: Science, v. 259, p. 906-908.

Davis, M.B., 1990, Biology and paleobiology of global climate change-introduction: TREE, v. 5, no. 9, p. 269-270.

Gallagher, R., 1997, Global initiative takes shape slowly: Science, v. 277, p. 309.

Gallagher, R.B., Fischman, J., and Hines, P.J., 1995, Big questions for a small planet: Science, v. 269 , p. 283.

Golombek, M.P., 1999, A message from warmer times: Science, v. 283, p. 1470-1471.

Goodman, S.M., and Patterson, B.D., 1998, Paradise in peril-examining the interaction of people and biota: American Scientist, v. 86, no. 1, p. 78-79.

Guzman, F., Ruiz, M.E., and Vega, E., 1996, Climate change consensus: Science, v. 271, p. $1042-1043$.

Hasselmann, K., 1997, Are we seeing global warming?: Science, v. 276, p. 914-915.

IGBP Terrestrial Carbon Working Group, 1998, The terrestrial carbon cycle-implications for the Kyoto protocol: Science, v. 280, p. 1393-1394.

Jakosky, B.M., 1999, Water, climate, and life: Science, v. 283, p. 648-649.

Johannessen, O.M., Bjorgo, E., and Miles, M.W., 1996, Global warming and the Arctic: Science, v. 271, p. 129.

Kaiser, J., 1998a, New network aims to take the world's $\mathrm{CO}_{2}$ pulse: Science, v. 281, p. 506-507.

Kaiser, J., 1998b, Possibly vast greenhouse gas sponge ignites controversy: Science, v. 282, p. 386-387.

Karl, T.R., Jones, P.D., and Knight, R.W., 1996, Testing for bias in the climate record: Science, v. 271, p. 1879-1883.

Kauppi, P.E., 1995, The United Nations climate convention-unattainable or irrelevant: Science, v. 270, p. 1454.

Kerr, R.A., 1997, The right climate for assessment: Science, v. 277, p. 1916-1918.

Klicka, J., and Zink, R.M., 1997, The importance of recent ice ages in speciation-a failed paradigm: Science, v. 277, p. 1666-1669.

Lubchenco, J., 1998, Entering the century of the environment-a new social contract for science: Science, v. 279, p. 491-496.

Mahlman, J.D., 1997, Uncertainties in projections of human-caused climate warming: Science, v. 278, p. 1416-1417. 
Malakoff, D., 1997, Thirty Kyotos needed to control warming: Science, v. 278, p. 2048.

Peel, D.A., 1993, Climate cycles-cold answers to hot issues: Nature (London), v. 363, no. 6428, p. 403-404.

Rasmussen, P.E., Goulding, K.W., Brown, F.R., Grace, P.R., Janzen, H.H., and Korschens, M., 1998, Long-term agroecosystem experiments-assessing agricultural sustainability and global change: Science, v. 282, p. 893-896.

Roberts, L., 1991, Academy panel split on greenhouse adaptation: Science, v. 253, p. 1206.

Root, T.L., and Schneider, S.H., 1995, Ecology and climate-research strategies and implications: Science, v. 269, p. 334-339.

Ruddiman, W.F., 1990, Changes in climate and biota on geologic time scales: TREE, v. 5, no. 9, p. 285-288.

Shukla, J., 1998, Predictability in the midst of chaos - a scientific basis for climate forecasting: Science, v. 282, p. 728-731.

Ward, P.D., 1998, The greenhouse extinction: Discover (August), p. 54-58.

Zillman, J.W., 1997, Atmospheric science and public policy: Science, v. 276, p. 1084-1086.

\section{Climate Modeling (and Forcing Mechanisms)}

Barron, E.J., and Moore, G.T., 1994, Climate Model Application in Paleoenvironmental Analysis: Tulsa, OK, SEPM Short Course Notes, v. 33, 339 p.

Bills, B.G., 1992, Orbital, rotational, and climatic interactions-lessons from earth and mars, in Clifford, S.M., Howard, A.D., and Paterson, W.S.B., eds., Workshop on the Polar regions of Mars: Geology, Glaciology, and Climate History: LPI Technical Report: Houston, TX, Lunar and Planetary Institute, p. 1-4.

COHMAP, 1988, Climatic changes of the last 18,000 years-observations and model simulations: Science, v. 241, p. 1043-1052.

Galushkin, Y., 1997, Numerical simulation of permafrost evolution as a part of sedimentary basin modeling-Permafrost in the Pliocene-Holocene climate history of the Urengoy Field in the West Siberian Basin: Canadian Journal of Earth Sciences, v. 34, no. 7, p. 935-948.

Graham, N.E., 1995, Simulation of recent global temperature trends: Science, v. 267, p. 666-671.

Hansen, J.E., Sato, M., Ruedy, R., Lacis, A., and Glascoe, J., 1998, Global climate data and model-a reconciliation: Science, v. 281, p. 930-933.

Kim, S.J., Crowly, T.J., and Stossel, A., 1998, Local orbital forcing of Antarctic climate change during the last interglacial: Science, v. 280, p. 728-730.

Krumenaker, L., 1994, In ancient climate, orbital chaos?: Science, v. 263, no. 1, p. 323.

Kutzbach, J.E., and Liu, Z., 1997, Response of the African monsoon to orbital forcing and ocean feedbacks in the middle Holocene: Science, v. 278, p. 440-443.

Lawton, J.H., 1995, Ecological experiments with model systems: Science, v. 269, p. 328-331.

McIntyre, A., 1997, Intertropical latitudes and precessional and half-precessional cycles: Science, v. 278, p. 1476-1478.

McIntyre, A., and Molfino, B., 1996, Forcing of Atlantic equatorial and subpolar millennial cycles by precession: Science, v. 274, p. 1867-1870.

Muller, R.A., and MacDonald, G.J., 1997, Glacial cycles and astronomical forcing: Science, v. 277 , p. 215-218. 
Olsen, P.E., Kent, D.V., and Cornet, B., 1992, Implications of orbitally forced 400,000 and 2,000,000 yr climate cycles (E. Mesozoic, eastern North America): Geological Society of America (Northeastern Section, 27th annual meeting) Abstracts with Programs, p. 67.

Raymo, M.E., and Ruddiman, W.F., 1992, Tectonic forcing of late Cenozoic climate: Nature, v. 359, p. 117-122.

Ruddiman, W.F., 1989, Informal reflections on some unsolved problems in orbital-scale climate cycles, in Bradley, R.S., ed., Global changes of the past: Boulder, CO, Office of Interdisciplinary Earth Studies, p. 357-363.

Sarmiento, J.L., and Quere, C.L., 1996, Oceanic carbon dioxide uptake in a model of centuryscale global warming: Science, v. 274, p. 1346-1350.

Sellers, P.J., Kickinson, R.E., Randall, D.A., Betts, A.K., Hall, F.G., Berry, J.A., Collatz, G.J., Denning, A.S., Mooney, H.A., Nobre, C.A., Sato, N., Field, C.B., and Henderson-Sellers, A., 1997, Modeling the exchanges of energy, water, and carbon between continents and the atmosphere: Science, v. 275, p. 502-509.

Taubes, G., 1997, Apocalypse not: Science, v. 278, p. 1004-1006.

Williams, D.F., Peck, J., Karabanov, E.B., Prokopenko, A.A., Kravchinsky, V., King, J., and Kuzmin, M.I., 1997, Lake Baikal record of continental climate response to orbital insolation during the past 5 million years: Science, v. 278, p. 1114-1117.

\section{Methods (Regardless of Subject)}

Albarede, F., 1997, Isotopic tracers of past ocean circulation-turning lead to gold: Science, v. 277, p. 908-909.

Bierman, P.R., Gillespie, A.R., and Caffee, M.W., 1995, Cosmogenic ages for earthquake recurrence intervals and debris flow fan deposition, Owens Valley, California: Science, v. 270 , p. $447-450$.

Bloemendal, J., and deMenocal, P.B., 1989, Evidence for a change in the periodicity of tropical climate cycles at 2.4 Myr from whole-core magnetic susceptibility measurements: Nature (London), v. 342, no. 6252, p. 897-900.

Dean, W.E., Ahlbrandt, T.S., Anderson, R.Y., and Bradbury, J.P., 1996, Regional aridity in North America during the middle Holocene: The Holocene, v. 6, no. 2, p. 145-155.

Edwards, R.L., Cheng, H., Murrell, M.T., and Goldstein, S.J., 1997, Protactinium-231 dating of carbonates by thermal ionization mass spectrometry-implications for Quaternary climate change: Science, v. 276, p. 782-786.

Eglinton, T.I., Benitez-Nelson, B.C., Pearson, A., McNichol, A.P., Bauer, J.E., and Druffel, E.R.M., 1997, Variability in radiocarbon ages of individual organic compounds from marine sediments: Science, v. 277, p. 796-798.

Feng, Z., Johnson, W.C., Lu, Y., and Ward, P.A., 1991, Climatic signals from loess-soil sequences in the central Great Plains, USA: Palaeogeography, Palaeoclimatology, Palaeoecology, v. 110, p. 345-358.

Forman, S.L, Goetz, A.F.H., and Yuhas, R.H., 1992. Large-scale stabilized dunes on the high plains of Colorado-understanding the landscape response to Holocene climates with the aid of images from space: Geology, v. 20, p. 145-148. 
Fredlund, G.G., and Tieszen, L.L., 1997, Phytolith and carbon isotope evidence for late Quaternary vegetation and climate change in the southern Black Hills, South Dakota: Quaternary Research, v. 47, p. 206-217.

Grootes, P.M., and Stuiver, M., 1986, Ross ice shelf oxygen isotopes and west Antarctic climate history: Quaternary Research (New York), v. 26, no. 1, p. 49-67.

Hanssen, R.F., Weckwerth, T.M., and Zebker, K., R., 1999, High-resolution water vapor mapping from interferometric radar measurements: Science, v. 283, p. 1297-1299.

Harris, R.N., and Chapman, D.S., 1997, Borehole temperatures and a baseline for 20th-century global warming estimates: Science, v. 275, p. 1618-1621.

Harrison, W.D., 1990, Climate history and equilibrium geothermal heat flux at Prudhoe Bay, Alaska: Eos, Transactions (1990 fall meeting), American Geophysical Union, p. 1603.

Herbert, T.D., and D' Hondt, S.L., 1990, Precessional climate cyclicity in Late Cretaceous-early Tertiary marine sediments; a high resolution chronometer of Cretaceous-Tertiary boundary events: Earth and Planetary Science Letters, v. 99, no. 3, p. 263-275.

Herzog, D.C., 1991, The earth's magnetic field and climate patterns: Geological Society of America (1991 annual meeting) Abstracts with Programs, p. 303.

Horowitz, A., 1989, Continuous pollen diagrams for the last $3.5 \mathrm{~m} . \mathrm{y}$. from Israel—vegetation, climate and correlation with the oxygen isotope record: Palaeogeography, Palaeoclimatology, Palaeoecology, v. 72, p. 63-78.

Horrell, M.A., 1989, A global-scale climate reconstruction of the Maestrichtian: methods and results of an integrated study: Geological Society of America Abstracts with Programs, v. 21, no. 6, p. A340.

Jacobson, H.A., and Engstrom, D.R., 1989, Resolving the chronology of recent lake sediments_ an example from Devils Lake, North Dakota: Journal of Palaeolimnology, v. 2, p. 81-98.

Jacoby, G.C., D'Arrigo, R.D., and Davaajamts, T., 1996, Mongolian tree rings and 20th-century warming: Science, v. 273, p. 771-773.

Karner, D.B., Renne, P., Alvarez, W., Ammerman, A.J., and Marra, F., 1994, ${ }^{40} \mathrm{Ar} /{ }^{39} \mathrm{Ar}$ dating of complex coastal deposits in Italy - a radiometric calibration of Pleistocene climate cycles: Geological Society of America, 1994 annual meeting, Abstracts with Programs, p. 257.

Kelts, K., Zao, C.K., Lister, G., Qing, Y.J., Hong, G.Z., Niessen, F., and Bonani, G., 1989, Geological fingerprints of climate history - a cooperative study of Qinghai Lake, China: Eclogae Geologicae Helvetiae, v. 82, no. 1, p. 167-182.

Kennedy, J.A., and Brassell, S.C., 1993, Molecular records of seasonal plankton productivity and annual climate cycles in the Guaymas Basin, Mexico: Eos, Transactions, American Geophysical Union (1993 fall meeting), p. 363.

Kursinski, E.R., Hajj, G.A., Bertinger, W.I., Leroy, S.S., Meehan, T.K., Romans, L.J., Schofield, J.T., McCleese, D.J., Melbourne, W.G., Thorton, C.L., Yunck, T.P., Eyre, J.R., and Nagatani, R.N., 1996, Initial results of radio occultation observations of Earth's atmosphere using the global positioning system: Science, v. 271, p. 1107-1110.

Li, J., Lowenstein, T.K., Godfrey, L.V., and Jordan, T.E., 1996, Andean climate history from a Holocene-Pleistocene salt core, Salar de Hombre Muerto, Argentina: Eos, Transactions, American Geophysical Union (1996 fall meeting), p. 304. 
Liritzis, I., and Kosmatos, D., 1995, Solar-climate cycles in a tree-ring record from Parthenon, in Finkl, C.W., ed., Holocene cycles_climate, sea levels, and sedimentation: Journal of Coastal Research (Fort Lauderdale, FL), Coastal Education and Research Foundation (CERF), p. 73-78.

Lowenstein, T.K., Li, J., Godfrey, L.V., and Jordan, T., 1996, Andean climate history from a Holocene-Pleistocene salt core, Salar de Hombre Muerto, Argentina: Geological Society of America (28th annual meeting): Abstracts with Programs, v. 28, no. 7, p. 498.

Marra, P.P., Hobson, K.A., and Holmes, R.T., 1998, Linking winter and summer events in a migratory bird by using stable-carbon isotopes: Science, v. 282, p. 1884-1886.

Matthews, J.V., Jr., and Schweger, C.E., 1985, Old Crow Tephra; its significance for understanding the early and middle Wisconsinan climate history of eastern Beringia, in Harington, C.R., ed., Climatic change in Canada-5, critical periods in the Quaternary climatic history of northern North America: Ottawa, Ontario, Canada, National Museum of Natural Sciences, p. 453-459.

Mora, C.I., Driese, S.G., and Colarusso, L.A., 1996, Middle to late Paleozoic atmospheric $\mathrm{CO}_{2}$ levels from soil carbonate and organic: Science, v. 271, p. 1105-1107.

Nesje, A., Kvamme, M., Rye, N., and Lovlie, R., 1991, Holocene glacial and climate history of the Jostedalsbreen region, western Norway-evidence from lake sediments and terrestrial deposits: Quaternary Science Reviews, v. 10, no. 1, p. 87-114.

Nilssen, E., and Vorren, K.D., 1991, Peat humification and climate history, in Hald, M., Larsen, E., Henriksen, K., and Vorren, K.D., eds., Climate of the northern latitudes; past, present and future; extended abstracts: Norsk Geologisk Tidsskrift: Oslo, Norway, Universitetsforlaget, p. 215-217.

Norris, G., 1982, Spore-pollen evidence for early Oligocene high-latitude cool climate episode in northern Canada: Nature, v. 297, p. 387-388.

Oglesby, R., and Park, J., 1989, The effect of precessional insolation changes on Cretaceous climate and cyclic sedimentation: Yale University.

Orem, W.H., Lerch, H.E., and Kotra, R.K., 1992, Lignin oxidation products in sediments of Lake Baikal, USSR - indicators of climate history of Northeast Asia: American Chemical Society (203rd National meeting) Abstracts of Papers, p. 83.

Pandolfi, L.J., Kalil, E.L., Doose, P.R., Levine, L.H., and Libby, L.M., 1980, Climate periods in trees and in organic carbon in sea sediment core, in Stuiver, M., and Kra, R.S., eds., Proceedings of the Tenth International Radiocarbon Conference: Radiocarbon (American Journal of Science), p. 740-745.

Plummer, M.A., Phillips, F.M., Fabryka-Martin, J., Turin, H.J., Wigand, P.E., and Sharma, P., 1997, Chlorine-36 in fossil rat urine-an archive of cosmogenic nuclide deposition during the past 40,000 years: Science, v. 277, p. 538-540.

Pollack, H.N., Haung, S., and Shen, P., 1998, Climate change record in subsurface temperatures-a global perspective: Science, v. 282, p. 279-281.

Rietti-Shati, M., Shemesh, A., and Karlen, W., 1998, A 3000-year climatic record from biogenic silica oxygen isotopes in equatorial high-altitude lake: Science, v. 281, p. 980-982.

Rignot, E.J., Gogineni, S.P., Krabill, W.B., and Ekholm, S., 1997, North and northeast Greenland ice discharge from satellite radar interferometry: Science, v. 276, p. 934-937.

Rossignol, S.M., and Planchais, N., 1989, Climate patterns revealed by pollen and oxygen isotope records of a Tyrrhenian Sea core: Nature (London), v. 342, no. 6248, p. 413-416. 
Rovner, I., 1999, Phytolith analysis: Science, v. 283, p. 488-489.

Safanda, J., Cermak, V., and Bodri, L., 1997, Climate history inferred from borehole temperatures, data from the Czech Republic, in Plag, H.P., and Klosko, S., eds., Geophysical evidence of past and present climate change: Surveys in Geophysics: DordrechtBoston, International, D. Reidel Publishing Company, p. 197-212.

Semeniuk, V., 1986, Holocene climate history of coastal southwestern Australia using calcrete as an indicator: Palaeogeography, Palaeoclimatology, Palaeoecology, v. 53, no. 2-4, p. 289-308.

Shackley, M.L., 1979, Climate history preserved in calcite: Geographical Magazine (London), v. 51, no. 4, p. 301-304.

Shotyk, W., Weiss, D., Appleby, P.G., Cheburkin, A.K., Frei, R., Gloor, M., Kramers, J.D., Reese, S., and Van Der Knaap, W.O., 1998, History of atmospheric lead deposition since $12,370{ }^{14} \mathrm{C}$ yr BP from a peat bog, Jura Mountains, Switzerland: Science, v. 281, p. $1635-1640$.

Smith, G.I., Barczak, V.J., Moulton, G.F., Liddicoat, J.C., Hay, R.L., Frey, D.G., Leopold, E.B., and Sarna, W.A.M., 1978, Three million years of climate history at Searles Lake.

Spicer, R.A., 1990, Fossils as environmental indicators-climate from plants, in Briggs, D.E.G., and Crowther, P.R., eds., Palaeobiology, Blackwell Scientific Publications, p. 401-406.

Yung, Y.L., Lee, T., Wang, C., and Shieh, Y., 1996, Dust-a diagnostic of the hydrologic cycle during the last glacial maximum: Science, v. 271, p. 962-963.

Zimov, S.A., Voropaev, Y.V., Semiletov, I.P., Davidov, S.P., Prosiannikov, S.F., Capin, F.S.I., Chapin, M.C., and Trumbore, S., Tyler, S., 1997, North Siberian lakes-a methane source fueled by Pleistocene carbon: Science, v. 277, p. 800-802.

\section{Anthropogenic Influence on Climate}

Abelson, P.H., 1997, Proposed air pollutant standards: Science, v. 277, p. 15.

Abelson, P.H., 1998, Airborne particulate matter: Science, v. 281, p. 1609.

Geotimes, 1997, Do human cause global climate change?: Geotimes, p. 14.

Hansen, J.E., M., S., Lacis, A., Ruedy, R., I., T., and Matthews, E., 1998, Climate forcings in the industrial era: National Academy of Sciences, v. 95, p. 12,753-12,758.

Hong, S., Candelone, J., Patterson, C.C., and Boutron, C.F., 1996, History of ancient copper smelting pollution during Roman and medieval times recorded in Greenland ice: Science, v. 272, p. 246-249.

Kerr, R.A., 1997, Contrails may alter climate: Science, v. 276, p. 1649.

Mahlman, J.D., 1997, Uncertainties in projections of human-caused climate warming: Science, v. 278 , p. 1416-1417.

Nriagy, J.O., 1996, A history of global metal pollution: Science, v. 272, p. 223-224.

Parson, E.A., and Keith, D.W., 1998, Fossil fuels without $\mathrm{CO}_{2}$ emissions: Science, v. 282, p. $1053-1054$.

Schwartz, S.E., and Andreae, M.O., 1996, Uncertainty in climate change caused by aerosols: Science, v. 272, p. 1121-1122. 
Shotyk, W., Weiss, D., Appleby, P.G., Cheburkin, A.K., Frei, R., Gloor, M., Kramers, J.D., Reese, S., and Van Der Knaap, W.O., 1998, History of atmospheric lead deposition since $12,370{ }^{14} \mathrm{C}$ yr BP from a peat bog, Jura Mountains, Switzerland: Science, v. 281, p. $1635-1640$.

Stanley, D.J., and Warne, A.G., 1997, Holocene sea-level change and early human utilization of deltas: GSA Today, v. 7, no. 12, p. 1-7.

Tett, S.F.B., Mitchell, J.F.B., Parker, D.E., and others, 1996, Human influence on the atmospheric vertical temperature structure-detection and observations: Science, v. 274, p. $1170-1173$.

Wigley, T.M.L., Smith, R.L., and Santer, B.D., 1998, Anthropogenic influence on the autocorrelation structure of hemispheric-mean temperatures: Science, v. 282, p. 1676-1679.

\section{Climate Change and the Atmosphere (Circulation, Gases, Ozone)}

Appenzeller, T., 1993, Searching for clues to ancient carbon dioxide: Science, v. 259, p. 908-909. Azar, C., and Rodhe, H., 1997, Targets for stabilization of atmospheric $\mathrm{CO}_{2}$ : Science, v. 276, p. $1818-1819$.

Berner, R.A., and Petsch, S.T., 1998, The sulfur cycle and atmospheric oxygen: Science, v. 282, p. $1426-1427$.

Boering, K.A., Wofsy, S.C., Daube, B.C., Schneider, H.R., Loewenstein, M., Podolske, J.R., and Conway, T.J., 1996, Stratospheric mean ages transport rates from observations of carbon dioxide and nitrous oxide: Science, v. 274, p. 1340-1343.

Brock, C.A., Hamill, P., Wilson, J.C., Jonsson, H.H., and Chan, K.R., 1995, Particle formation in the upper tropical troposphere - a source of nuclei for the stratospheric aerosol: Science, v. 270, p. 1650-1653.

Brook, E.J., Sowers, T., and Orchard, J., 1996, Rapid variations in atmospheric methane concentrations during the past 110,000 years: Science, v. 273, p. 1087-1090.

Brummer, D., Staigelin, J., and Jeker, D., 1998, Large-scale nitrogen oxide plumes in the tropopause region and implications for ozone: Science, v. 282, p. 1305-1309.

Chameides, W.L., Saylor, R.D., and Cowling, E.B., 1997, Ozone pollution in the rural United States and the new NAAQS: Science, v. 276, p. 916.

Dickerson, R.R., Kondragunta, S., Stenchikov, G., Civerolo, K.L., Doddridge, B.G., and Holben, B.N., 1997, The impact of aerosols on solar ultraviolet radiation and photochemical smog: Science, v. 278, p. 827-830.

Farquhar, G.H., 1997, Carbon dioxide and vegetation: Science, v. 278, p. 1411.

Fox, L.E., Worsnop, D.R., Zahniser, M.S., and Wofsy, S.C., 1995, Metastable phases in polar stratospheric aerosols: Science, v. 267, p. 351-355.

Frankingnoulle, M., Abril, G., Borges, A., Bourge, I., Canon, C., Delille, B., Libert, E., and Theate, J.M., 1998, Carbon dioxide emission from European estuaries: Science, v. 282, p. 434-436.

Frink, C.R., 1996, Acid rain revisited?: Science, v. 273, p. 293-295.

Ganopolski, A., Kubatzki, C., Claussen, M., Brovkin, V., and Petoukhov, V., 1998, The influence of vegetation-atmosphere-ocean interaction on climate during the mid-Holocene: Science, v. 280, p. 1916-1919. 
Gard, E.E., Kleeman, M.J., Gross, D.S., Hughes, L.S., Allen, J.O., Morrical, B.D., Fergenson, D.P., Dienes, T., Galli, M.E., Jognson, R.J., Cass, G.R., and Prather, K.A., 1998, Direct observation of heterogeneous chemistry in the atmosphere: Science, v. 279, p. 1184-1187.

Gellene, G.I., 1996, An explanation for symmetry-induced isotopic fractionation in ozone: Science, v. 274, p. 1344.

Grace, J., Lloyd, J., McIntyre, J., Miranda, A.C., Meir, P., Miranda, H.S., Nobre, C., Moncrieff, J., Massheder, J., Malhi, Y., Wright, I., and Gash, J., 1995, Carbon dioxide uptake by an undisturbed tropical rain forest in southwest Amazonia, 1992-1993: Science, v. 270, p. 778-780.

Hanson, B., 1993, Evolution of atmospheres: Science, v. 259, p. 875.

Hatfield, D.B., 1996, Reducing greenhouse gases: Science, v. 271, p. 431.

Haywood, J.M., Ramaswamy, V., and Soden, B.J., 1999, Tropospheric aerosol climate forcing in clear-sky satellite observations over the oceans: Science, v. 283, p. 1299-1306.

Hebestreit, K., Stutz, J., Rosen, D., Matveiv, V., Peleg, M., Luria, M., and Platt, U., 1999, DOAS measurements of tropospheric bromine oxide in mid-latitudes: Science, v. 283, p. $55-57$.

Hedin, L.O., and Likens, G.E., 1996, Atmospheric dust and acid rain: Scientific American, v. 275, no. 6 , p. 88-92.

Hobbs, P.V., Reid, J.S., Kotchenruther, R.A., Ferek, R.J., and Weiss, R., 1997, Direct radiative forcing by smoke from biomass burning: Science, v. 275, p. 1776-1778.

Jiang, Y., and Yung, Y.L., 1996, Concentrations of tropospheric ozone from 1979 to 1992 over tropical Pacific South America from TOMS data: Science, v. 272, p. 714-716.

Jolly, D., and Haxeltine, A., 1997, Effect of low glacial atmospheric $\mathrm{CO}_{2}$ on tropical African montane vegetation: Science, v. 276, p. 786-788.

Jones, T.H., Thompson, L.J., Lawton, J.H., Bezemer, T.M., Bardgett, R.D., Blackburn, T.M., Bruce, K.D., Cannon, P.F., Hall, G.S., Hartley, S.E., Howson, G., Jones, C.G., Kampichler, C., Kandeler, E., and Ritchie, D.A., 1998, Impacts of rising atmospheric carbon dioxide on model terrestrial ecosystems: Science, v. 280, p. 441-443.

Kaufman, Y.J., and Fraser, R.S., 1997, The effect of smoke particles on clouds and climate forcing: Science, v. 277, p. 1636-1639.

Kerr, R.A., 1995, Greenhouse report foresees growing global stress: Science, v. 270, p. 731.

Kerr, R.A., 1996, Ozone-destroying chlorine tops out: Science, v. 271, p. 32.

Kerr, R.A., 1998, Acid rain control-success on the cheap: Science, v. 282, p. 1024-1027.

Kerr, R.A., 1998, Ozone loss, greenhouse gases linked: Science, v. 280, p. 202.

Kerr, R.A., 1999, Big el Niños ride the back of slower climate change: Science, v. 283, p. $1108-1109$.

Kiehl, J.T., 1999, Solving the aerosol puzzle: Science, v. 283, p. 1273-1275.

Kley, D., Crutzen, P.J., Smit, H.G., Vomel, H., Oltmans, S.J., Grassl, H., and Ramanathan, V., 1996, Observations of near-zero ozone concentrations over the convective Pacific-effects on air chemistry: Science, v. 274, p. 230-233.

Krankowsky, D., and Mauersberger, K., 1996, Heavy ozone-a difficult puzzle to solve: Science, v. 274, p. 1324-1325.

Kump, L.R., and Mackenzie, F.T., 1996, Regulation of atmospheric $\mathrm{O}_{2}$-feedback in the microbial feedbag: Science, v. 271, p. 459-460.

Likens, G.E., 1998, Solving the acid rain problem: Science, v. 282, p. 1991-1992. 
Likens, G.E., Driscoll, C.T., and Busco, D.C., 1996, Long-term effects of acid rain-response and recovery of a forest ecosystem: Science, v. 272, p. 244-246.

Likens, G.E., Wright, R.F., Galloway, J.N., and Butler, T.J., 1979, Acid rain: Scientific American, v. 241 , no. 4 , p. 43-51.

Mahlman, J.D., 1997, Dynamics of transport processes in the upper troposphere: Science, v. 276, p. $1079-1083$.

Meng, Z., Dabdub, D., and Seinfeld, J. H., 1997, Chemical coupling between atmospheric ozone and particulate matter: Science, v. 277, p. 116-119.

Moffat, A.S., 1997, Resurgent forests can be greenhouse gas sponges: Science, v. 277, p. 315-316.

Montzka, S.A., Butler, J.H., Myers, R.C., Thompson, T.M., Swanson, T.H., Clarke, A.D., Lock, L.T., and Elkins, J.W., 1996, Decline in the tropospheric abundance of halogen from halocarbons-implications for stratospheric ozone depletion: Science, v. 272, p. 1318-1322.

Mudur, G., 1995, Monsoon shrinks with aerosol models: Science, v. 270, p. 1922.

Odum, J.R., Jungkamp, T.P.W., Griffin, R.J., Flagan, R.C., and Seinfeld, J.H., 1997, The atmospheric aerosol-forming potential of whole gasoline vapor: Science, v. 276, p. 96-99.

Oum, K.W., Lakin, M.J., DeHaan, D.O., Brauers, T., and Finlayson-Pitts, B.J., 1998, Formation of molecular chlorine from the photolysis of ozone and aqueous sea-salt particles: Science, v. 279, p. 74-77.

Pennisi, E., 1998, Global nitrogen overload problem grows critical: Science, v. 279, p. 988-989.

Peter, T., 1996, Airborne particle analysis for climate studies: Science, v. 273, p. 1352-1353.

Prather, M.J., 1997, Time scales in atmospheric chemistry—coupled perturbations to $\mathrm{N}_{2} \mathrm{O}, \mathrm{NO}_{\mathrm{y}}$, and $\mathrm{O}_{3}$ : Science, v. 279, p. 1339-1340.

Ravishankara, A.R., Hancock, G., Kawasaki, M., and Matsumi, Y., 1998, Photochemistry of ozone-surprises and recent lessons: Science, v. 280, p. 60-61.

Robock, A., 1996, Stratospheric control of climate: Science, v. 272, p. 972-973.

Roscoe, H.K., Jones, A.E., and Lee, A.M., 1997, Midwinter start to Antarctic ozone depletion-evidence from observations and models: Science, v. 278, p. 93-96.

Schwartz, S.E., and Andreae, M.O., 1996, Uncertainty in climate change caused by aerosols: Science, v. 272, p. 1121-1122.

Sellers, P.J., Bounoua, L., Collatz, G.J., Randall, D.A., Dazlich, D.A., Los, S.O., Berry, J.A., Fung, I., Tucker, C.J., Field, C.B., and Jensen, T.G., 1996, Comparison of radiative and physiological effects of doubled atmospheric $\mathrm{CO}_{2}$ on climate: Science, v. 271, p. 1402-1406.

Stephens, G.L., 1996, How much solar radiation do clouds absorb?: Science, v. 271, p. $1360-1361$.

Strauss, E., 1998, Coming to grips with the world's greenhouse gases: Science, v. 281, p. 504-505.

Street-Perrott, F., Huang, Y., Perrott, R.A., Eglinton, G., Barker, P., Khelifa, L.B., Harkness, D.D., and Olago, D.O., 1997, Impact of lower atmospheric carbon dioxide on tropical mountain ecosystems: Science, v. 278, p. 1422-1426.

Summers, M.E., Conway, R.R., Siskind, D.E., Stevens, M.H., Offermann, D., Riese, M., Preusse, P., Strobel, D.F., and Russell, J.M.I., 1997, Implications of satellite OH observations for middle atmospheric $\mathrm{H}_{2} \mathrm{O}$ and ozone: Science, v. 277, p. 1967-1970.

Sundquist, E.T., 1993, The global carbon dioxide budget: Science, v. 259, p. 934-942. 
Tett, S.F.B., Mitchell, J.F.B., Parker, D.E., and Allen, M.R., 1996, Human influence on the atmospheric vertical temperature structure-detection and observations: Science, v. 274, p. $1170-1173$.

Thiemens, M.H., Jackson, T., Zipf, E.C., Erdman, P.W., and van Egmond, C., 1995, Carbon dioxide and oxygen isotope anomalies in the mesosphere and stratosphere: Science, v. 270, p. 969-972.

Tolbert, M.A., 1996, Polar clouds and sulfate aerosols: Science, v. 272, p. 1597-1598.

Trumbore, S.E., Chadwick, O.A., and Amundson, R., 1996, Rapid exchange between soil carbon and atmospheric carbon dioxide driven by temperature change: Science, v. 272, p. 393-396.

Valero, F.P.J., Collins, W.D., Pilewskie, P., Bucholtz, A., and Flatau, P.J., 1997, Direct radiometric observations of the water vapor greenhouse effect over the equatorial Pacific Ocean: Science, v. 275, p. 1773-1776.

Viggiano, A.A., Morris, R.A., Gollinger, K., and Arnold, F., 1995, Ozone destruction by chlorine - the impracticality of mitigation through ion chemistry: Science, v. 267, p. 82-84.

Volk, T., 1989, Sensitivity of climate and atmospheric $\mathrm{CO}_{2}$ to deep-ocean and shallow-ocean carbonate burial: Geology, p. 1-3.

Williams, N., 1997, el Niño slows greenhouse gas buildup?: Science, v. 278, p. 802.

\section{Climate Cycles (and Milankovitch)}

Barnes, P.M., 1994, Pliocene-Pleistocene depositional units on the continental slope off central New Zealand-Control by slope currents and global climate cycles: Marine Geology, v. 117, no. $1-4$, p. 155-175.

Benson, L.V., Burdett, J.W., Kashgarian, M., Lund, S.P., Phillips, F.M., and Rye, R.O., 1996, Climatic and hydrologic oscillations in the Owens Lake basin and adjacent Sierra Nevada, California: Science, v. 274, p. 746-749.

Bond, G., Showers, W., Cheseby, M., Lotti, R., Almasi, P., deMenocal, P., Priore, P., Cullen, H., Hajdas, I., and Bonani, G., 1997, A pervasive millennial-scale cycle in North Atlantic Holocene and glacial climates: Science, v. 278, p. 1257-1266.

Bradley, W.H., 1938, A brief annotated bibliography on cyclic variations in climate as indicated by pre-Pleistocene non-glacial varves: Bulletin of the American Meteorological Society, v. 19, no. 5 , p. 162-163.

Broecker, W.S., 1992, Climate cycles—upset for Milankovitch theory: Nature (London), v. 359, no. 6398, p. 779-780.

Broecker, W., 1999, Climate change prediction: Science, v. 283, p. 175.

Dia, A.N., Cohen, A.S., O'Niells, R., and Shackleton, N.J., 1992, Seawater Sr isotope variation over the past $300 \mathrm{kyr}$ and influence of global climate cycles: Nature (London), v. 356, no. 6372 , p. 786-788.

Flohn, H., 1979, Can climate history repeat itself? Possible climatic warming and the case of paleoclimatic warm phases, in Bach, W., Pankrath, J., and Kellogg, W., eds., Man's impact on climate: Amsterdam, Netherlands, Elsevier Sci. Publ. Co., p. 15-28.

Frazen, L., 1994, Are wetlands key to the ice-age cycle enigma?: Ambio, v. 23, no. 4-5, p. 300-308.

Gillette, H.P., 1939, A system of harmonic weather and climate cycles: Roads \& Streets, v. 82, no. 11 , p. 47-48. 
Griffies, S.M., and Bryan, K., 1997, Predictability of North Atlantic multidecadal climate variability: Science, v. 275, p. 181-184.

Gu, D., and Philander, S.G.H., 1997, Interdecadal climate fluctuations that depend on exchanges between the tropics and extratopics: Science, v. 275, p. 805-807.

Jarrard, R.D., and Golovchenko, X., 1988, Milankovitch climate cycles in ODP wireline logs: American Association of Petroleum Geologists Bulletin, v. 72, p. 201.

Karner, D.B., Renne, P., Alvarez, W., Ammerman, A.J., and Marra, F., 1995, ${ }^{40} \mathrm{Ar} /{ }^{39} \mathrm{Ar}$ geochronology of the Tiber River delta, Italy-how well does Milankovitch predict the timing of middle Pleistocene climate cycles?: Geological Society of America (1995 annual meeting) Abstracts with Programs, p. 175.

Kerr, R.A., 1981, Milankovitch climate cycles_old and unsteady: Science, v. 213, no. 4512, p. 1095-1096.

Kerr, R.A., 1987, Milankovitch climate cycles through the ages: Science, v. 235, no. 4792, p. 973-974.

Kerr, R.A., 1994, Milankovitch plays climate in double-time in the tropics: Science, v. 163, p. $174-175$.

Kerr, R.A., 1997, Sea floor records reveal interglacial climate cycles: Science, v. 279, p. 1304-1305.

Kerr, R.A., 1997, Second clock supports orbital pacing of the ice ages: Science, v. 276, p. 680-681.

Kerr, R.A., 1997, Upstart ice age theory gets attentive but chilly hearing: Science, v. 277, p. $183-184$.

Kerr, R.A., 1998, Sea floor records reveal interglacial climate cycles: Science, v. 279, no. 5355, p. 1304-1305.

Kortenkamp, S.J., and Dermott, S.F., 1998, A 100,000-year periodicity in the accretion rate of interplanetary dust: Science, v. 280, p. 874-876.

Libby, L.M., and Pandolfi, L.J., 1977, Climate periods in tree, ice and tides: Nature (London), v. 266, no. 5601, p. 415-417.

Morrell, V., 1996, Evolving rhythms: Science, v. 271, p. 906.

Morrisette, P.M., 1988, The stability bias and adjustment to climatic variability-the case of the rising level of the Great Salt Lake: Applied Geography, v. 8, p. 171-189.

Oppo, D., 1997, Millennial climate oscillations: Science, v. 278, p. 1244-1246.

Phillips, F.M., Campbell, A.R., Smith, G.I., and Bischoff, J.L., 1994, Interstadial climate cycles—a link between western North America and Greenland?: Geology (Boulder), v. 22, no. 12, p. 1115-1118.

Prather, M.J., 1997, Time scales in atmospheric chemistry—coupled perturbations to $\mathrm{N}_{2} \mathrm{O}, \mathrm{NO}_{\mathrm{x}}$, and $\mathrm{O}_{3}$ : Science, v. 279, p. 1339-1340.

Sarmiento, J.L., and Quere, C.L., 1996, Oceanic carbon dioxide uptake in a model of centuryscale global warming: Science, v. 274, p. 1346-1350.

Schreiner, J., Voigt, C., Kohlmann, A., Arnold, F., Mauersberger, K., and Larsen, N., 1999, Chemical analysis of polar stratospheric cloud particles: Science, v. 283, p. 968-970.

Shukla, J., 1998, Predictability in the midst of chaos-a scientific basis for climate forecasting: Science, v. 282, p. 728-731.

Stahle, D.W., Cleaveland, M.K., Blanton, D.B., Therrell, M.D., and Gay, D.A., 1998, The lost colony and Jamestown droughts: Science, v. 280, p. 564-566. 
Swetnam, T.W., 1992, Annual to millennial-scale fire and climate patterns in the Sierra Nevada, California, U.S.A: American Quaternary Association (12th biennial meeting) Program and Abstracts, p. 27.

Uppenbrink, J., 1997, Seasonal climate prediction: Science, v. 277, p. 1952.

Yu, Z., and Eicher, U., 1998, Abrupt climate oscillations during the last deglaciation in central North America: Science, v. 282, p. 2235-2238.

\section{Climate Change in the Holocene}

Beck, W., 1998, Warmer and wetter 6000 years ago?: Science, v. 279, p. 1003-1004.

Hebda, R.J., 1993, Climate history, Heal Lake, Vancouver Island, British Columbia, CANQUA 93, Program with Abstracts and Field Guide: Applied Quaternary Research Association, Canada, p. A20.

Keigwin, L.D., 1996, The Little Ice Age and medieval warm period in the Sargasso Sea: Science, v. 274, p. 1504-1508.

Kerr, R.A., 1997, Cores document ancient catastrophe: Science, v. 275, p. 1265.

Kreutz, K.J., Mayewski, P.A., Meeker, L.D., Twickler, M.S., Whitlow, S.I., and Pittalwala, I.I., 1997, Bipolar changes in atmospheric circulation during the Little Ice Age: Science, v. 277, p. 1294-1296.

Mackenzie, F.T., and Kump, L.R., 1995, Reverse weathering, clay mineral formation, and oceanic element cycles: Science, v. 270, p. 586-587.

Mangerud, J., Svendsen, J.I., Elverhoi, A., Andersen, E., and Solheim, A., 1992, Late Weichselian and early Holocene glacial and climate history of western Spitsbergen, Svalbard: Eos, Transactions (1992 fall meeting) American Geophysical Union, p. 259.

Nesje, A., Kvamme, M., Rye, N., and Lovlie, R., 1991, Holocene glacial and climate history of the Jostedalsbreen region, western Norway-evidence from lake sediments and terrestrial deposits: Quaternary Science Reviews, v. 10, no. 1, p. 87-114.

Nullet, D., 1989, Recent climate history of Hawaii: Pacific Science, v. 43, no. 1, p. 96-101.

O'Brien, S.R., Mayewski, P.A., Meeker, L.D., Meese, D.A., Twickler, M.S., and Whitlow, S.I., 1995, Complexity of Holocene climate as reconstructed from a Greenland ice core: Science, v. 270, p. 1962-1964.

Overpeck, J., Hughen, K., Hardy, D., Bradley, R., Case, R., Douglas, M., Finney, B., Gajewski, K., Jacoby, G., Jennings, A., S., L., Lasca, A., MacDonald, G., Moore, J., Retelle, M., Smith, S., Wolfe, A., and Zielinski, G., 1997, Arctic environmental change of the last four centuries: Science, v. 278, p. 1251-1256.

Rietti-Shati, M., Shemesh, A., and Karlen, W., 1998, A 3000-year climatic record from biogenic silica oxygen isotopes in equatorial high-altitude lake: Science, v. 281, p. 980-982.

Sandweiss, D.H., Maasch, K.A., and Anderson, D.G., 1999, Transitions in the mid-Holocene: Science, v. 283, p. 499-500.

Shafer, D.S., 1989, Holocene climate patterns inferred from pollen and macrofossil records of Holocene lakes of the northern Colorado Plateau, Utah and Arizona: Geological Society of America (Cordilleran Section, 85th, and Rocky Mountain Section, 42nd, annual meetings) Abstracts with Programs, p. 142.

Singer, C., Shulmeister, J., and McLea, B., 1998, Evidence against a significant Younger Dryas cooling event in New Zealand: Science, v. 281, p. 812-814. 
Sirocko, F., Garbe-Schonberg, D., Mclntyre, A., and Molfino, B., 1996, Teleconnections between the subtropical monsoons and high-latitude climates during the last deglaciation: Science, v. 272, p. 526-529.

Stager, J.C., and Mayewski, P.A., 1997, Abrupt early to mid-Holocene climatic transition registered at the equator and the poles: Science, v. 274, p. 1834-1836.

Stanley, D.J., and Warne, A.G., 1997, Holocene sea-level change and early human utilization of deltas: GSA Today, v. 7, no. 12, p. 1-7.

Taylor, K.C., Mayewski, P.A., Alley, R.B., Brook, J.B., Gow, A.J., Grootes, P.M., Meese, D.A., Saltzman, E.S., Severinghaus, J.P., Twickler, M.S., White, J.W.C., Whitlow, S., and Linski, G.A., 1997, The Holocene-Younger Dryas transition recorded at summit, Greenland: Science, v. 278, p. 825-826.

Yu, Z., and Eicher, U., 1998, Abrupt climate oscillations during the last deglaciation in central North America: Science, v. 282, p. 2235-2238.

\section{Climate Change and Temperatures}

Balling, R.C., Jr., and Cerveny, R.S., 1995, Influence of lunar phase on daily global temperatures: Science, v. 267, p. 1481-1483.

Cane, M.A., Clement, A.C., Kaplan, A., Kushnir, Y., Pozdnyakow, D., Seager, R., Zebiak, S.E., and Murtugudde, R., 1997, Twentieth-century sea surface temperature trends: Science, v. 275, p. 957-960.

Cuffey, K.M., Clow, G.D., Alley, R.B., Stuiver, M., Waddington, E.D., and Saltus, R.W., 1995, Large Arctic temperature change at the Wisconsin-Holocene glacial transition: Science, v. 270, p. 455-458.

Dahl-Jensen, D., Mosegaard, K., Gundestrup, N., Clow, G.D., Johnsen, S.J., Hansen, A.W., and Balling, N., 1998, Past temperatures directly from the Greenland ice sheet: Science, v. 282, p. 268-271.

Easterling, D.R., Horton, B., Jones, P.D., Peterson, T.C., Karl, T.R., Parker, D.E., Salinger, M.J., Razuvayev, V., Plummer, N., Jamason, P., and Folland, C.K., 1997, Maximum and minimum temperature trends for the globe: Science, v. 277, p. 364-367.

Gagan, M.K., Ayliffe, L.K., Hopley, D., Cali, J.A., Mortimer, G.E., Chappell, J., McCulloch, M.T., and Head, J., 1998, Temperature and surface-ocean water balance of the midHolocene tropical western Pacific: Science, v. 279, p. 1014-1018.

Groisman, P.Y., Karl, T.R., and Knight, R.W., 1994, Observed impact of snow cover on the heat balance and the rise of continental spring temperatures: Science, v. 263, p. 198-200.

Guilderson, T.P., and Schrag, D.P., 1998, Abrupt shift in subsurface temperatures in the tropical pacific associated with changes in el Niño: Science, v. 281, p. 240-243.

Harris, R.N., and Chapman, D.S., 1997, Borehole temperatures and a baseline for 20th-century global warming estimates: Science, v. 275, p. 1618-1621.

Harrison, W.D., 1990, Climate history and equilibrium geothermal heat flux at Prudhoe Bay, Alaska: Eos, Transactions (1990 fall meeting), American Geophysical Union, p. 1603.

Jacoby, G.C., D'Arrigo, R.D., and Davaajamts, T., 1996, Mongolian tree rings and 20th-century warming: Science, v. 273, p. 771-773.

Kerr, R.A., 1996, 1995 the warmest year? Yes and no: Science, v. 271, p. 137-138. 
Kerr, R.A., 1998, Among global thermometers, warming still wins out: Science, v. 281, p. 1948-1949.

Kerr, R.A., 1998, The hottest year, by a hair: Science, v. 279, p. 315-316.

Kerr, R.A., 1998, Warming's unpleasant surprise—shivering in the greenhouse?: Science, v. 281, p. $156-158$.

MacAyeal, D., 1995, Challenging an ice-core paleothermometer: Science, v. 270, p. 444-445.

Safanda, J., Cermak, V., and Bodri, L., 1997, Climate history inferred from borehole temperatures-data from the Czech Republic, in Plag, H.P., and Klosko, S., eds., Geophysical evidence of past and present climate change-surveys in Geophysics: Dordrecht-Boston, International, D. Reidel Publishing Company, p. 197-212.

Sear, C.B., Kelley, P.M., Jones, P.D., and Goodess, C.M., 1987, Global surface temperature responses to major volcanic eruptions: Nature, v. 330, p. 365-367.

Stute, M., Forster, M., Frischkorn, H., Serejo, A., Clark, J.F., Schlosser, P., Broecker, W.S., and Bonani, G., 1995, Cooling of tropical Brazil $\left(5^{\circ} \mathrm{C}\right)$ during the last glacial maximum: Science, v. 269, p. 379-382.

Wallace, J.M., Zhang, Y., and Renwick, J.A., 1995, Dynamic contribution to hemispheric mean temperature trends: Science, v. 270, p. 780-783.

Wolfe, J.A., 1979, Temperature parameters of humid to mesic forests of eastern Asia and relation to forests of other regions in the northern hemisphere: U.S. Geological Survey Professional Paper, v. 1106, p. 37.

\section{Climate Change and Solar Activity}

Arking, A., 1996, Absorption of solar energy in the atmosphere: Discrepancy between model and observations: Science, v. 273, p. 779-782.

Anderson, O.L., 1999, A thermal balancing act: Science, v. 283, p. 1652-1653.

Covey, C., 1996, Sun-climate links: Science, v. 272, p. 179.

Glanz, J., 1996, Unruly sun emerges in solar observatory's first results: Science, v. 273, p. $179-180$.

Haigh, J.D., 1996, The impact of solar variability on climate: Science, v. 272, p. 981-984.

Kerr, R.A., 1997, Did satellites spot a brightening sun?: Science, v. 277, p. 1923-1924.

Liritzis, I., and Kosmatos, D., 1995, Solar-climate cycles in a tree-ring record from Parthenon, in Finkl, C.W., ed., Holocene cycles_climate, sea levels, and sedimentation: Journal of Coastal Research (Fort Lauderdale, FL), Coastal Education and Research Foundation (CERF), p. 73-78.

Kerr, R.A., 1996, A new dawn for sun-climate links?: Science, v. 271, p. 1360-1361.

\section{Climate Change from Vegetation Studies (Paleosols)}

Ager, T.A., and Bradbury, J.P., 1983, Late Quaternary vegetation and climate history from western Alaska: U.S. Geological Survey Professional Paper 1375, p 162, 163.

Allen, G., 1995, Vegetation and climate history of south Vancouver Island [Master's thesis]: Vancouver, British Columbia, University of Victoria.

Allen, G.B., and Hebda, R.J., 1995, Late-Quaternary vegetation and climate history of the coastal Douglas-fir biogeoclimatic zone of south Vancouver Island, British Columbia, in Geological 
Association of Canada (annual meeting): Waterloo, ON, Canada, Geological Association of Canada, p. 1.

Alward, R.D., Detling, J.K., and Michunas, K.G., 1999, Grassland vegetation changes and nocturnal global warming: Science, v. 283, p. 229-231.

Anderson, R.S., 1993, A 35,000 year vegetation and climate history from Potato Lake, Mogollon Rim, Arizona: Quaternary Research (New York), v. 40, no. 3, p. 351-359.

Baker, R.G., Maher, L.J., Chumbley, C.A., Van Zant, K.L, 1992, Patterns of Holocene environmental change in the midwestern United States: Quaternary Research, v. 37, p. 379-389.

Barnosky, C.W., 1989, Postglacial vegetation and climate in the northwestern Great Plains of Montana: Quaternary Research, v. 31, p. 57-73.

Behling, H., 1997, Late Quaternary vegetation, climate and fire history of the Araucaria forest and Campos region from Serra Campos Gerais, Parana State (South Brazil): Review of Palaeobotany and Palynology, v. 97, no. 1-2, p. 109-121.

Berner, R.A., 1997, The rise of plants and their effect on weathering and atmospheric $\mathrm{CO}_{2}$ : Science, v. 276, p. 544-546.

Bierman, P., Lini, A., Zehfuss, P.C., A., Davis, P.T., Southon, J., and Baldwin, L., 1997, Postglacial ponds and alluvial fans-recorders of Holocene landscape history: GSA Today, v. 7 , no. 10 , p. $1-39$.

Braswell, B.H., Schimel, D.S., Linder, E., and Moore III, B., 1997, The response of global terrestrial ecosystems to interannual temperature variability: Science, v. 278, p. 870-872.

Brozovic, N., Burbank, D.W., and Meigs, A.J., 1997, Climatic limits on landscape development in the northwestern Himalaya: Science, v. 276, p. 571-574.

Brugam, R.B., 1980, Postglacial diatom stratigraphy of Kirchner Marsh, Minnesota: Quaternary Research, v. 13, p. 133-146.

Christophel, D.C., and Greenwood, D.R., 1989, Changes in climate and vegetation in Australia during the Tertiary: Review of Palaeobotany and Palynology, v. 58, p. 95-109.

Davis, J.M., and Taylor, S.E., 1980, Leaf physiognomy and climate-a multivariate analysis: Quaternary Research, v. 14, p. 337-348.

Dixon, R.K., Brown, S., Houghton, R.A., Solomon, A.M., Trexler, M.C., and Wisniewski, J., 1994, Carbon pools and flux of global forest ecosystems: Science, v. 263, p. 185-189.

Dolph, G.E., 1978, Variation in leaf size and margin type with respect to climate: Cour. Forsch.Inst. Senckenberg, v. 30, p. 153-158.

Dolph, G.E., and Dilcher, D.L., 1980a, Variation in leaf size with respect to climate in Costa Rica: Biotropica, v. 12, no. 2, p. 91-99.

Dolph, G.E., and Dilcher, D.L., 1980b, Variation in leaf size with respect to climate in the tropics of the western hemisphere: Bull. Torrey Botanical Club, v. 107, p. 154-162.

Dorale, J.A., Edwards, R.L., Ito, E., and Gonzalez, L.A., 1998, Climate and vegetation history of the midcontinent from 75 to $25 \mathrm{ka}$ : a speleothem record from Crevice Cave, Missouri, USA: Science, v. 282, p. 1871-1874.

Einarsson, T., 1963, Pollen-analytical studies on the vegetation and climate history of Iceland in late and post-glacial times, in Loeve, A., and Loeve, D., eds., North Atlantic biota and their history: Oxford, United Kingdom, Pergamon Press, p. 355-365.

Eronen, M., Zetterberg, P., and Lindholm, M., 1994, Climate history from tree rings in the subarctic area of Fennoscandia, in Kanninen, M., and Heikinheimo, P., eds., The Finnish 
Research Programme on Climate Change, Second Progress Report [Suomen Akatemian Julkaisuja]:The Academy of Finland, Helsinki, Finland, Suomen Akatemia, p. 13-19.

Farquhar, G.H., 1997, Carbon dioxide and vegetation: Science, v. 278, p. 1411.

Francis, J.E., 1988, A 50 million-year-old fossil forest from Strathcona Fiord, Ellesmere Island, Arctic Canada-evidence for a warm polar climate: Arctic, v. 41, no. 4, p. 314-318.

Fredlund, G.G., and Tieszen, L.L., 1997, Phytolith and carbon isotope evidence for late Quaternary vegetation and climate change in the southern Black Hills, South Dakota: Quaternary Research, v. 47, p. 206-217.

Fritz, S.C., Juggins, S., Battarbee, R.W., and Engstrom, D.R., 1991, Reconstruction of past changes in salinity and climate using a diatom-based transfer function: Nature, v. 352, p. 706-708.

Glaser, P.H., Bennett, P.C., Siegel, D.I., Romanowicz, E.A., 1996, Palaeo-reversals in groundwater flow and peatland development at Lost River, Minnesota, USA: The Holocene, v. 6 , no. 4 , p. 413-421.

Goulden, M.L., Wofsy, S.C., J.W., H., Trumbore, S.E., Crill, P.M., Gower, S.T., Fries, T., Daube, B.C., Fan, S.-M., Sutton, D.J., Bazzaz, A., and Munger, J.W., 1998, Sensitivity of boreal forest carbon balance to soil thaw: Science, v. 279, p. 214-217.

Grimm, E.C., and Clark, J.S., 1998, Holocene vegetation and climate change in the Northern Great Plains-evidence from pollen and charcoal studies: Geological Society of America (1998 annual meeting) Abstracts with Programs, p. 250.

Harte, J., and Shaw, R., 1995, Shifting dominance within a montane vegetation community—results of a climate-warming experiment: Science, v. 267, p. 876-880.

Heusser, C.J., 1990, Ice age vegetation and climate of subtropical Chile: Palaeogeography, Palaeoclimatology, Palaeoecology, v. 80, p. 107-127.

Horowitz, A., 1989, Continuous pollen diagrams for the last $3.5 \mathrm{~m} . \mathrm{y}$. from Israel—vegetation, climate and correlation with the oxygen isotope record: Palaeogeography, Palaeoclimatology, Palaeoecology, v. 72, p. 63-78.

Hotchkiss, S., 1997, Late-Quaternary climate history from Hawaiian pollen records: Geological Society of America (Cordilleran Section, 93rd annual meeting) Abstracts with Programs, p. 19-20.

Igarashi, Y., 1994, Quaternary forest and climate history of Hokkaido, Japan, from marine sediments: Quaternary Science Reviews, v. 13, no. 4, p. 335-344.

Isacks, B.L., 1992, "Long-term" land surface processes-erosion, tectonics and climate history in mountain belts, in Mather, P.M., ed., TERRA-1, Understanding the terrestrial environment; the role of Earth observations from space: London, United Kingdom, Taylor \& Francis, p. 21-36.

Islebe, G.A., and Hooghiemstra, H., 1997, Vegetation and climate history of montane Costa Rica since the last glacial: Quaternary Science Reviews, v. 16, no. 6, p. 589-604.

Jahns, S., Huels, M., and Sarnthein, M., 1998, Vegetation and climate history of West Equatorial Africa based on a marine pollen record off Liberia (site GIK 16776) covering the last 400,000 years: Review of Palaeobotany and Palynology, v. 102, no. 3-4, p. 277-288.

Jolly, D., and Haxeltine, A., 1997, Effect of low glacial atmospheric $\mathrm{CO}_{2}$ on tropical African montane vegetation: Science, v. 276, p. 786-788.

Jordan, G.J., Carpenter, R.J., and Hill, R.S., 1991, Late Pleistocene vegetation and climate near Melaleuca Inlet, south-western Tasmania: Australian Journal of Botany, v. 39, p. 315-333. 
Karner, D.B., and Marra, F., 1998, Correlation of fluviodeltaic aggradational sections with glacial climate history; a revision of the Pleistocene stratigraphy of Rome: Geological Society of America Bulletin, v. 110, no. 6, p. 748-758.

Kremenetski, C.V., 1995, Holocene vegetation and climate history of southwestern Ukraine: Review of Palaeobotany and Palynology, v. 85, no. 3-4, p. 289-301.

Kukla, G., 1989, Long continental records of climate—an introduction: Palaeogeography, Palaeoclimatology, Palaeoecology, v. 72, p. 1-9.

Lewin, R., 1984, Fragile forests implied by Pleistocene pollen: Science, v. 22, p. 36-37.

McCulloch, M.T., Tudhope, A.W., Esat, T.M., Mortimer, G.E., Chappell, J., Pillans, B., Chivas, A.R., and Omura, A., 1999, Coral record of equatorial sea-surface temperatures during the penultimate deglaciation at Huon Peninsula: Science, v. 283, p. 202-204.

McGlone, M.S., and Bathgate, J.L., 1983, Vegetation and climate history of the Longwood Range, South Island, New Zealand, 12000 BP to the present: New Zealand Journal of Botany, v. 21, no. 3, p. 293-315.

Mora, C.I., Driese, S.G., and Colarusso, L.A., 1996, Middle to late Paleozoic atmospheric $\mathrm{CO}_{2}$ levels from soil carbonate and organic: Science, v. 271, p. 1105-1107.

Peteet, D., Andreev, A., Bardeen, W., and Mistretta, F., 1998, Long-term Arctic peatland dynamics, vegetation and climate history of the Pur-Taz region, western Siberia: Boreas, v. 27 , no. 2, p. 115-126.

Rodbell, D.T., Seltzer, G.O., Anderson, D.M., Abbott, M.B., Enfield, D.B., and Newman, J.H., 1999, A 15,000-year record of el Niño-driven alluviation in southwestern Ecuador: Science, v. 283 , p. $516-520$.

Swetnam, T.W., 1992, Annual to millennial-scale fire and climate patterns in the Sierra Nevada, California, U.S.A: American Quaternary Association (12th biennial meeting) Program and Abstracts, p. 27.

Tang, L., 1992, Vegetation and climate history at Menghai, Yunnan during the past 42,000 years: Acta Micropalaeontologica Sinica (Weiti Gushengwu Xuebao), v. 9, no. 4, p. 433-455.

Thompson, R.S., Hostetler, S.W., Bartlein, P.J., and Anderson, K.H., 1998, A strategy for assessing potential future changes in climate, hydrology, and vegetation in the western United States: U.S. Geological Survey Circular 1153, 20 p.

Trumbore, S.E., Chadwick, O.A., and Amundson, R., 1996, Rapid exchange between soil carbon and atmospheric carbon dioxide driven by temperature change: Science, v. 272, p. 393-396.

Tzedakis, P.C., 1993, Long-term tree populations in Northwest Greece through multiple Quaternary climate cycles: Nature (London), v. 364, no. 6436, p. 437-440.

Webb III, T., 1986, Is vegetation in equilibrium with climate? How to interpret late-Quaternary pollen data: Vegetation, v. 67, p. 75-91.

Webb III, T., Bartlein, P.J., Harrison, S.P., and Anderson, K.H., 1993, Vegetation, lake levels, and climate in eastern North America for the past 18,000 years, in Wright, H.E., Webb III, T., and Kutzbach, J.E., eds., Global climates since the last glacial maximum: Minneapolis, University of Minnesota Press, p. 415-467.

Wolfe, J.A., 1979, Temperature parameters of humid to mesic forests of eastern Asia and relation to forests of other regions in the Northern Hemisphere: U.S. Geological Survey Professional Paper, v. 1106, p. 37.

\section{Climate Change from Faunal Data}


Barry, J.P., Baxter, C.H., Sagarin, R.D., and Gilman, S.E., 1995, Climate-related, long-term faunal changes in a California rocky intertidal community: Science, v. 267, p. 672-675.

Forester, R.M., 1991, Pliocene-climate history of the western United States derived from lacustrine ostracodes, in Cronin, T.M., and Dowsett, H.J., eds., Pliocene climates: Quaternary Science Reviews: Oxford, United Kingdom, Pergamon, p. 133-146.

Forester, R.M., Colman, S.M., Reynolds, R.L., and Keigwin, L.D., 1994, Lake Michigan's late Quaternary limnological and climate history from ostracode, oxygen isotope, and magnetic susceptibility, in Folger, D.W., Colman, S.M., and Barnes, P.W., eds., The southern Lake Michigan coastal erosion study: Journal of Great Lakes Research [Shelburne, ON, Canada]: International Association for Great Lakes Research (IAGLR), p. 93-107.

Fritz, S.C., 1990, Twentieth-century salinity and water-level fluctuations in Devils Lake, North Dakota - test of a diatom-based transfer function: Limnology and Oceanography, v. 35, no. 9, p. 1771-1781.

Fritz, S.C., Engstrom, D.R., Haskell, B.J., 1994, "Little Ice Age" aridity in the North American Great Plains - a high-resolution reconstruction of salinity fluctuations from Devils Lake, North Dakota, USA: The Holocene, v. 4, no. 1, p. 69-73.

Graham, R.W., 1990, Effects of global climate change on the patterns of terrestrial biological communities: TREE, v. 5, no. 9, p. 289-293.

Group, F.W., 1996, Spatial response of mammals to late Quaternary environmental fluctuations: Science, v. 272, p. 1601-1606.

Johnson, T.C., Scholz, C.A., Talbot, M.R., Kelts, K., Ricketts, R.D., Ngobi, G., Beuning, K., Ssemmanda, I., and McGill, J.W., 1996, Late pleistocene desiccation of Lake Victoria and rapid evolution of cichlid fishes: Science, v. 273, p. 1091-1093.

Kaufman, A., and Magaritz, M., 1980, The climate history of the eastern Mediterranean as recorded in mollusk shells, in Stuiver, M., and Kra, R.S., eds., Proceedings of the Tenth International Radiocarbon Conference: Radiocarbon: New Haven, CT, American Journal of Science, p. 778-781.

Kerr, R.A., 1992, When climate twitches, evolution takes great leaps: Science, v. 257, p. $1622-1624$.

Kerr, R.A., 1997, Climate-evolution link weakens: Science, v. 276, p. 1968.

Kerr, R.A., 1998, Deep-sea coral records quick response to climate: Science, v. 280, p. 679.

Markwick, P.J., 1994, "Equability," continentality, and Tertiary "climate" - the crocodilian perspective: Geology, v. 22, no. 7, p. 613-616.

Potts, R., 1996, Evolution and climate variability: Science, v. 273, p. 922-923.

Shafer, D.S., 1989, Holocene climate patterns inferred from pollen and macrofossil records of Holocene lakes of the northern Colorado Plateau, Utah and Arizona: Geological Society of America (Cordilleran Section, 85th, and Rocky Mountain Section, 42nd, annual meetings) Abstracts with Programs, p. 142.

Smith, F.A., Betancourt, J.L., and Brown, J.H., 1995, Evolution of body size in the woodrat over the past 25,000 years of climate change: Science, v. 270, p. 2012-2014.

Ward, P.D., 1998, The greenhouse extinction: Discover (August), p. 54-58.

Wing, S.L., and Greenwood, D.R., 1993, Fossils and fossil climate-the case for equable continental interiors in the Eocene: Philosophical Transactions of the Royal Society of London, v. 341, p. 243-252. 
Worona, M.A., 1993, Late-Quaternary vegetation and climate history of the central Coast Range, Oregon-A record of the last ca. 42,000 years from Little Lake, 83 p.

Worona, M.A., and Whitlock, C., 1995, Late Quaternary vegetation and climate history near Little Lake, central Coast Range, Oregon: Geological Society of America Bulletin, v. 107, no. 7, p. 867-876.

\section{Climate Change from Ice Records (and Modern Glaciers)}

Alley, R.B., and Bender, M.L., 1998, Greenland ice cores-frozen in time: Scientific American, v. 278 , no. 2, p. 80-85.

Appenzeller, C., Stecker, T.F., and Anklin, M., 1998, North Atlantic oscillation dynamics recorded in Greenland ice cores: Science, v. 282, p. 446-449.

Bender, M., Sowers, T., Dickson, M., Orchardo, J., Grootes, P., Mayewski, P.A., and Meese., D.A., 1994, Climate correlations between Greenland and Antarctica during the past 100,000 years: Nature, v. 372, p. 663-666.

Bentley, C.R., 1997, Rapid sea-level rise soon from west Antarctic ice sheet collapse?: Science, v. 275, p. 1077-1078.

Cavalieri, D.J., Gloersen, P., Parkinson, C.L., Comisco, J.C., and Zwally, H.J., 1997, Observed hemispheric asymmetry in global sea ice changes: Science, v. 278, p. 1104-1106.

Craig, H., and Wiens, R.C., 1996, Gravitational enrichment of ${ }^{84} \mathrm{Kr} /{ }^{36} \mathrm{Ar}$ ratios in polar ice caps-a measure of firn thickness and accumulation temperature: Science, v. 271, p. 1708-1710.

Dahl-Jensen, D., Mosegaard, K., Gundestrup, N., Clow, G.D., Johnsen, S.J., Hansen, A.W., and Balling, N., 1998, Past temperatures directly from the Greenland ice sheet: Science, v. 282, p. 268-271.

Dansgaard, W., and others, 1993, Evidence for general instability of past climate from a 250-kyr ice-core record: Nature, v. 364, p. 218-220.

Davis, C.H., Kluever, C.A., and Haines, B.J., 1998, Elevation change of the southern Greenland ice sheet: Science, v. 279, p. 2086-2088.

Fahnestock, M., 1996, An ice shelf breakup: Science, v. 271, p. 775-776.

Fischer, H., Wahlen, M., Smith, J., Mastroianni, D., and Deck, B., 1999, Ice core records of atmospheric $\mathrm{CO}_{2}$ around the last three glacial terminations: Science, v. 283, p. 1712-1714.

Grootes, P.M., and Stuiver, M., 1986, Ross ice shelf oxygen isotopes and west Antarctic climate history: Quaternary Research, v. 26, no. 1, p. 49-67.

Kerr, R.A., 1996, Ice bubbles confirm big chill: Science, v. 272, p. 1584-1585.

Kerr, R.A., 1996, Ice rhythms - core reveals a plethora of climate cycles: Science, v. 274, no. 5287, p. 499-500.

Krabill, W., Frederick, E., Manizade, S., Martin, C., Sonntag, J., Swift, R., Thomas, R., Wright, W., and Yungel, J., 1999, Rapid thinning of parts of the southern Greenland ice sheet: Science, v. 283, p. 1522-1524.

Lindner, B.L., 1992, Is $\mathrm{CO}_{2}$ ice permanent?, in Clifford, S.M., Howard, A.D., and Paterson, W.S.B., eds., Workshop on the polar regions of Mars-geology, glaciology, and climate history: LPI Technical Report [Houston, TX], Lunar and Planetary Institute, p. 16, 17.

MacAyeal, D., 1995, Challenging an ice-core paleothermometer: Science, v. 270, p. 444-445. 
Mayewski, P.A., Twickler, M.S., Whitlow, S.I., Meeker, L.D., Yang, Q., Thomas, J., Dreutz, K., Grootes, P.M., Morse, D.L., Steig, E.J., Waddington, E.D., Saltzman, E.S., Whung, P.-Y., and Taylor, K.C., 1996, Climate change during the last deglaciation in Antarctica: Science, v. 272, p. 1636-1638.

O'Brien, S.R., Mayewski, P.A., Meeker, L.D., Meese, D.A., Twickler, M.S., and Whitlow, S.I., 1995, Complexity of Holocene climate as reconstructed from a Greenland ice core: Science, v. 270, p. 1962-1964.

Oeschger, H., Beer, J., Siegenthaler, U., Stauffer, B., Dansgaard, W., and Langway, C.C., 1983, Late-glacial climate history from ice cores, in Ghazi, A., ed., Palaeoclimatic research and models, report and proceedings, workshop: Brussels and Belgium, D. Reidel Publ. Co., Dordrecht, Netherlands, Comm. Eur., p. 95-107.

Oeschger, H., Beer, J., Siegenthaler, U., Stauffer, B., Dansgaard, W., and Langway, C.C., 1984, Late glacial climate history from ice cores, in Hansen, J.E., and Takahashi, T., eds., Climate processes and climate sensitivity: Washington, DC, American Geophysical Union, Geophysical Monograph, p. 299-306.

Petit, J.R., Basile, I., Leruyuet, A., Raynaud, D., Lorius, C., Jouzel, J., Stievenard, M., Lipenkov, V.Y., Barkov, N.I., Kudryashov, B.B., Davis, M., Saltzman, E., and Kotlyakov, V., 1997, Four climate cycles in Vostok ice core: Nature (London), v. 387, no. 6631, p. 359-360.

Raynaud, D., Jouzel, J., Barnola, J.M., Chappellaz, J., Delmas, R.J., and Lorius, C., 1993, The ice record of greenhouse gases: Science, v. 259, p. 926-934.

Rignot, E.J., Gogineni, S.P., Krabill, W.B., and Ekholm, S., 1997, North and northeast Greenland ice discharge from satellite radar interferometry: Science, v. 276, p. 934-937.

Rott, H., Skvarca, P., and Nagler, T., 1996, Rapid collapse of Northern Larsen ice shelf, Antarctica: Science, v. 271, p. 788-792.

Thompson, L.G., Davis, M.E., Mosley, T.E., Sowers, T.A., Henderson, K.A., Zagorodnov, V.S., Lin, P.N., Mikhalenko, V.N., Campen, R.K., Bolzan, J.F., Cole, D.J., and Francou, B., 1998, A 25,000-year tropical climate history from Bolivian ice cores: Science, v. 282, no. 5395, p. 1858-1864.

Wingham, D.J., Ridout, A.J., Scharroo, R., Arthern, R.J., and Shum, C.K., 1998, Antarctic elevation change from 1992 to 1996: Science, v. 282, p. 456-458.

\section{Ocean Circulation}

Adkins, J.F., Cheng, H., Boyle, E.A., Druffel, E.R.M., and Edwards, R.L., 1998, Deep-sea coral evidence for rapid change in ventilation of the deep North Atlantic 15,400 years ago: Science, v. 280, p. 725-728.

Albarede, F., 1997, Isotopic tracers of past ocean circulation-turning lead to gold: Science, v. 277, p. 908-909.

Andel, T.H. v.an, Heath, G.R., Moore, T.C., and McGeary, D.F.R., 1967, Late Quaternary history, climate, and oceanography of the Timor sea, northwestern Australia: American Journal of Science, v. 265, no. 9, p. 737-758.

Arrigo, K.R., Robinson, D.H., Worthen, D.L., Dunbar, R.B., DiTullio, G.R., VanWoert, M., and Lizotte, M.P., 1999, Phytoplankton community structure and the drawdown of nutrients and $\mathrm{CO}_{2}$ in the southern ocean: Science, v. 283, p. 365-367. 
ATOC Consortium, 1998, Ocean climate change-comparison of acoustic tomography, satellite altimetry, and modeling: Science, v. 281, p. 1327-1332.

Azam, F., 1998, Microbial control of oceanic carbon flux - the plot thickens: Science, v. 280, p. 694-696.

Beauford, L., Lancelot, Y., Camberlin, P., Cayre, O., Vincent, E., Bassinot, F., and Labeyrie, L., 1997, Insolation cycles as a major control of equatorial Indian Ocean primary production: Science, v. 278, p. 1451-1454.

Bice, K.L., and Barron, E.J., 1997, Early Cenozoic thermohaline variability driven by possible changes in subtropical moisture fluxes: Earth System Science Center, Penn State University.

Bjorck, S., Kromer, B., Johnsen, S., Bennike, O., Hammarlund, D., Lemdahl, G., Possnert, G., Rasmussen, T.L., Woglfarth, B., Hammer, C.U., and Spurk, M., 1996, Synchronized terrestrial-atmospheric deglacial records around the North Atlantic: Science, v. 274, p. 1155-1160.

Boyd, P., and Newton, P., 1997, Measuring biogenic carbon flux in the ocean: Science, v. 275, p. 554-555.

Broecker, W.S., 1997, Thermohaline circulation, the Achilles heel of our climate system: Will man-made $\mathrm{CO}_{2}$ upset the current balance?: Science, v. 278, p. 1582-1588.

Broecker, W.S., 1999, What if the conveyor were to shut down? Reflections on a possible outcome of the great global experiment: GSA Today, v. 9, no. 1, p. 1-4.

Bryan, K., 1997, The dynamics of the seas: Science, v. 275, p. 1076.

Bush, A.B.G., 1998, The role of ocean-atmosphere interactions in tropical cooling during the last glacial maximum: Science, v. 279, p. 1341-1344.

Cane, M.A., 1998, A role for the tropical Pacific: Science, v. 282, p. 59-61.

Cane, M.A., Clement, A.C., Kaplan, A., Kushnir, Y., Pozdnyakow, D., Seager, R., Zebiak, S.E., and Murtugudde, R., 1997, Twentieth-century sea surface temperature trends: Science, v. 275, p. 957-960.

Chelton, D.B., and Schlax, M.G., 1996, Global observations of oceanic Rossby waves: Science, v. 272, p. 234-238.

Christensen, J.N., Halliday, A.N., Godfry, L.V., Hein, J.R., and Rea, D.K., 1997, Climate and ocean dynamics and the lead isotopic records in Pacific ferromanganese crusts: Science, v. 277, p. 913-918.

Druffel, E.R.M., 1997, Pulses of rapid ventilation in the North Atlantic surface ocean during the past century: Science, v. 275, p. 1454-1457.

Dwyer, G.S., Cronin, T.M., Baker, P.A., Raymo, M.E., Buzas, J.S., and Correge, T., 1995, North Atlantic deepwater temperature change during late Pliocene and late Quaternary climatic cycles: Science, v. 270, p. 1347-1351.

Esat, T.M., McCulloch, M.T., Chappell, J., Pillans, B., and Omura, A., 1999, Rapid fluctuations in sea level recorded at Huon Peninsula during the penultimate deglaciation: Science, v. 283, p. 197-201.

Fan, S., Gloor, M., Mahlaman, J., Pacala, S., Sarmiento, J., Takahashi, T., and Tans, P., 1998, A large terrestrial carbon sink in North America implied by atmospheric and oceanic carbon dioxide data and models: Science, v. 282, p. 442-446.

Field, C.B., Behrenfeld, M.J., Randerson, J.T., and Falkowski, P., 1998, Primary production of the biosphere-integrating terrestrial and oceanic components: Science, v. 281, p. 237-240. 
Fletcher, C.H., III, Van, P.J.E., Brush, G.S., and Sherman, J., 1993, Tidal wetland record of Holocene sea-level movements and climate history: Palaeogeography, Palaeoclimatology, Palaeoecology, v. 102, nos. 3-4, p. 177-213.

Gagan, M.K., Ayliffe, L.K., Hopley, D., Cali, J.A., Mortimer, G.E., Chappell, J., McCulloch, M.T., and Head, J., 1998, Temperature and surface-ocean water balance of the midHolocene tropical western Pacific: Science, v. 279, p. 1014-1018.

Ganopolski, A., Kubatzki, C., Claussen, M., Brovkin, V., and Petoukhov, V., 1998, The influence of vegetation-atmosphere-ocean interaction on climate during the mid-Holocene: Science, v. 280, p. 1916-1919.

Griffies, S.M., and Bryan, K., 1997, Predictability of North Atlantic multidecadal climate variability: Science, v. 275, p. 181-184.

Jin, F.F., 1996, Tropical ocean-atmosphere interaction, the Pacific cold tongue, and the el Niñosouthern oscillation: Science, v. 274, p. 76-78.

Jones, G.A., 1991, A stop-start ocean conveyer: Nature, v. 349, p. 364-365.

Kerr, R.A., 1997, A new driver for the Atlantic's moods and Europe's weather?: Science, v. 275, p. 754-755.

Li, M., Zahariev, K., and Garrett, C., 1995, Role of Langmuir circulation in the deepening of the ocean surface mixed layer: Science, v. 270, p. 1955-1957.

Lozier, M.S., 1997, Evidence for large-scale eddy-driven gyres in the North Atlantic: Science, v. 277, p. 361-364.

Lu, G., Adatte, T., Keller, G., and Ortiz, N., in press (1996), Abrupt climatic, oceanographic and ecologic changes near the Paleocene-Eocene transition in the deep Tethys Basin: Paleoceanography.

Mackensen, A., and Ehrmann, W.U., 1992, Middle Eocene through early Oligocene climate history and paleoceanography in the southern ocean-stable oxygen and carbon isotopes from ODP sites on Maud Rise and Kerguelen Plateau: Marine Geology, v. 108, no. 1, p. $1-27$.

Masiello, C.A., and Druffel, E.R.M., 1998, Black carbon in deep-sea sediments: Science, v. 280, p. 1911-1913.

McManus, J.F., Oppo, D.W., and Cullen, J.L., 1999, A 0.5 million-year record of millennial-scale climate variability in the North Atlantic: Science, v. 283, p. 971-975.

Nakamura, H., and Yamagata, T., 1998, Oceans and climate shifts: Science, v. 274, p. 1144.

Nerem, R.S., 1997, Global mean seal level change_correction: Science, v. 275, p. 1053.

Picaut, J., Ioualalen, M., Menkes, C., Delcroix, T., and McPhaden, M.J., 1996, Mechanism of the zonal displacements of the Pacific warm pool-implications for ENSO: Science, v. 274, p. $1486-1489$.

Polzin, K.L., Toole, J.M., Ledwell, J.R., and Schmitt, R.W., 1997, Spatial variability of turbulent mixing in the abyssal ocean: Science, v. 276, p. 93-96.

Rasmusson, E.M., 1985, el Niño and variations in climate: Am. Sci., v. 73, p. 168-176.

Sandweiss, K.H., Richardson, J.B., III, Reitz, E.J., Rollins, H.B., and Maasch, K.A., 1996, Geoarchaeological evidence from Peru for a 5000 years B.P. onset of el Niño: Science, v. 273, p. 1531-1533.

Schrag, D.P., Hampt, G., and Murray, D.W., 1996, Pore fluid constraints on the temperature and oxygen isotopic composition of the glacial ocean: Science, v. 272, p. 1930-1932. 
Stieg, E.J., Brook, E.J., White, J.W.C., Sucher, C.M., Bender, M.L., Lehman, S.J., Morse, D.L., Waddington, E.D., and Clow, G.D., 1998, Synchronous climate changes in Antarctica and the North Atlantic: Science, v. 282, p. 92-95.

Sun, D.-Z., and Liu, Z., 1996, Dynamic ocean-atmosphere coupling-a thermostat for the tropics: Science, v. 272, p. 1148-1150.

Uppenbrink, J., 1999, The North Atlantic oscillation: Science, v. 283, p. 948-949.

Vanandel, T.H., Heath, G.R., Moore, T.C., and McGeary, D.F.R., 1967, Late quaternary history, climate, and oceanography of the Timor sea, northwestern Australia: American Journal of Science, v. 265, no. 9, p. 737-758.

Williams, N., 1997, el Niño slows greenhouse gas buildup?: Science, v. 278, p. 802.

Williamson, P., and Holligan, P.M., 1990, Ocean productivity and climate change: TREE, v. 5, no. 9, p. 299-303.

Wilson, C.R., 1998, Oceanic effects on earth's rotation rate: Science, v. 281, p. 1623-1624.

\section{Climate Change and Glacial Activity}

Bard, E., 1997, Nuclide production by cosmic rays during the last ice age: Science, v. 277, p. 532-533.

Beyerle, U., Purtschert, R., Aeschbach-Hertig, W., Imboden, D.M., Loosli, H.H., Wieler, R., and Kipfer, R., 1998, Climate and groundwater recharge during the last glaciation in an icecovered region: Science, v. 282, p. 731-734.

Broecker, W., 1996, Glacial climate in the tropics: Science, v. 272, p. 1902-1904.

Cuffey, K.M., Clow, G.D., Alley, R.B., Stuiver, M., Waddington, E.D., and Saltus, R.W., 1995, Large Arctic temperature change at the Wisconsin-holocene glacial transition: Science, v. 270 , p. $455-458$.

Esat, T.M., McCulloch, M.T., Chappell, J., Pillans, B., and Omura, A., 1999, Rapid fluctuations in sea level recorded at Huon Peninsula during the penultimate deglaciation: Science, v. 283, p. 197-201.

Kassens, H., Bauch, H.A., and Hoelemann, J.A., 1995, The Laptev Sea system-a key to Arctic Ocean climate history, in Global change and marine geology; 85. Jahrestagung der Geologischen Vereinigung e. V.; Zusammenfassung der Tagungsbeitraege: Terra Nostra: Bonn, Federal Republic of Germany, Alfred-Wegener-Stiftung, p. 24.

Kerr, R.A., 1996, Ice-age rain forest found moist, cooler: Science, v. 274, p. 35-36.

Muller, R.A., and MacDonald, G.J., 1997, Glacial cycles and astronomical forcing: Science, v. 277, p. 215-218.

Oppo, D.W., McManus, J.F., and Cullen, J.L., 1998, Abrupt climate events 500,000 to 340,000 years ago: Evidence from subpolar North Atlantic sediments: Science, v. 279, p. 1335-1338.

Rudnick, D.L., and Ferrari, R., 1999, Compensation of horizontal temperature and salinity gradients in the ocean mixed layer: Science, v. 283, p. 526-529.

Stute, M., Forster, M., Frischkorn, H., Serejo, A., Clark, J.F., Schlosser, P., Broecker, W.S., and Bonani, G., 1995, Cooling of tropical Brazil $\left(5^{\circ} \mathrm{C}\right)$ during the last glacial maximum: Science, v. 269, p. 379-382.

\section{Pre-Quaternary Climate Change (Important Times in Geologic History)}


Adatte, T., Keller, G., and Stinnesbeck, W., 1996, Increased volcanism, sea-level and climate fluctuations through the K/T boundary-mineralogical evidences, in The Cretaceous-Tertiary boundary: biological and geological aspects: Séance Spécialisée De La Société Géologique De France [unpaginated], Paris.

Aubry, M.-P., 1998, Early Paleogene calcareous nannoplankton evolution-a tale of climatic amelioration, in Aubry, M.-P., Lucas, S., and Berggren, W., eds., Late Paleocene-early Eocene climatic and biotic events in marine and terrestrial records: New York, Columbia University Press, p. 158-203.

Aubry, M.-P., Berggren, W.A., Stott, L., and Sinha, A., 1996, The upper Paleocene-lower Eocene stratigraphic record and the Paleocene-Eocene boundary carbon isotope excursion-implications for geochronology, in Knox, R.W.O.B., Corfield, R.M., and Dunay, R.E., eds., Correlation of the early Paleogene in northwest Europe: Geological Society Special Publication, p. 353-380.

Barron, E.J., Thompson, S.L., and Schneider, S.H., 1981, An ice-free Cretaceous? Results from climate model simulations: Science, v. 212, no. 4494, p. 501-508.

Batten, D.J., 1984, Palynology, climate and the development of Late Cretaceous floral provinces in the northern hemisphere-a review, in Brenchly, P., ed., Fossils and climate, John Wiley and Sons Ltd., p. 127-164.

Batten, D.J., and Wenben, L., 1987, Aspects of palynomorph distribution, floral provinces and climate during the Cretaceous: Geol. Jb., v. A96, p. 219-237.

Berner, R.A., 1990, Atmospheric carbon dioxide levels over Phanerozoic time: Science, v. 249, p. 1382-1386.

Blaine, C.C., 1993, Mississippian and Pennsylvanian climate history of the eastern United States and the origin of refractory clay deposits, in Kvale, E.P., ed., Symposium on the Economic Resources of the Lower Pennsylvanian of the Illinois Basin: Bloomington, IN, Indiana Geological Survey Open-File Report, p. 11.

Boyd, A., 1990, The Thyra $\varnothing$ flora: Toward an understanding of the climate and vegetation during the early Tertiary in the high Arctic: Review of Paleobotany and Palynology, v. 62, p. 189-203.

Cecil, C.B., 1993, Carboniferous climate history of the Ozark Dome and the Eastern and Western Interior basins: Geological Society of America (North-Central Section) Abstracts with Programs, p. 11.

Crowley, T.J., and North, G.R., 1988, Abrupt climate change and extinction events in earth history: Science, v. 240, p. 996-1002.

Crowley, T.J., Short, D.A., Mengel, J.G., and North, G.R., 1986, Role of seasonality in the evolution of climate during the last 100 million years: Science, v. 231, p. 579-584.

Fleming, R.F., 1994, Cretaceous pollen in Pliocene rocks-Implications for Pliocene climate in the southwestern United States: Geology, v. 22, p. 787-790.

Frakes, L.A., and Francis, J.E., 1990, Cretaceous palaeoclimates, in Ginsburg, R.N., and Beaudoin, B., eds., Cretaceous resources, events and rhythms: Dordrecht, Netherlands, Kluwer Academic Publishers, p. 273-278.

Golombek, M.P., 1999, A message from warmer times: Science, v. 283, p. 1470-1471.

Graham, A., 1992, Utilization of the isthmian land bridge during the Cenozoic_paleobotanical evidence for timing, and the selective influence of altitudes and climate: Review of Palaeobotany and Palynology, v. 72, p. 119-128. 
Gregory, K.M., and Chase, C.G., 1992, Tectonic significance of paleobotanically estimated climate and altitude of the late Eocene erosion surface, Colorado: Geology, v. 20, p. 581-585.

Herbert, T.D., and D'Hondt, S.L., 1990, Precessional climate cyclicity in Late Cretaceous-early Tertiary marine sediments - a high resolution chronometer of Cretaceous-Tertiary boundary events: Earth and Planetary Science Letters, v. 99, no. 3, p. 263-275.

Herman, A.B., 1994, Late Cretaceous Arctic platanoids and high latitude climate, in Boulter, M.C., and Fisher, H.C., eds., Cenozoic plants and climates of the Arctic: Berlin, Springer-Verlag, p. 151-159.

Horrell, M.A., 1989, A global-scale climate reconstruction of the Maestrichtian: methods and results of an integrated study: Geological Society of America Abstracts with Programs, v. 21, no. 6, p. A340.

Huber, B.T., 1998, Tropical paradise at the Cretaceous poles?: Science, v. 282, p. 2199-2200.

Huber, B.T., Hodell, D.A., and Hamilton, C.P., 1995, Middle-Late Cretaceous climate of the southern high latitudes: Stable isotopic evidence for minimal equator-to-pole thermal gradients: Geological Society of America Bulletin, v. 107, no. 10, p. 1164-1191.

Keller, G., Lu, G., Adatte, T., and Benjamini, C., 1995, Abrupt change in the upwelling system along the southern margin of the Tethys during the Paleocene-Eocene transition event: Earth Science, v. 44, p. 185-195.

Kennett, J.P., and Barker, P.F., 1990, Latest Cretaceous to Cenozoic climate and oceanographic developments in the Weddel Sea, Antarctica - an ocean-drilling perspective: Proceedings of the ODP, Scientific Results, v. 113, p. 937.

Kennett, J.P., and Robert, C., 1992, Paleocene and Eocene kaolinite distribution in the South Atlantic and southern ocean: Antarctic climatic and paleoceanographic implications: Marine Geology, v. 103, p. 99-110.

Kerr, R.A., 1998, Argentina, and perhaps its life, took a hit: Science, v. 282, p. 1965-1966.

Koch, P., and Zachos, J.C., 1991, Chronostratigraphy and paleoclimate of the Paleocene-Eocene boundary in the Western Interior of North America, in Chapman Conference, Continental Isotopic Indicators of Climate: Washington, DC, American Geophysical Union.

Lu, G., Adatte, T., Keller, G., and Ortiz, N., in press (1996), Abrupt climatic, oceanographic and ecologic changes near the Paleocene-Eocene transition in the deep Tethys Basin: Paleoceanography.

Mackensen, A., and Ehrmann, W.U., 1992, Middle Eocene through early Oligocene climate history and paleoceanography in the Southern Ocean; stable oxygen and carbon isotopes from ODP Sites on Maud Rise and Kerguelen Plateau: Marine Geology, v. 108, no. 1, p. 1-27.

Mackenzie, F.T., and Kump, L.R., 1995, Reverse weathering, clay mineral formation, and oceanic element cycles: Science, v. 270, p. 586-587.

Macphail, M.K., Hill, R.S., Forsyth, S.M., and Wells, P.M., 1991, A late Oligocene-early Miocene cool climate flora in Tasmania: Alcheringa, v. 15, p. 87-106.

Markwick, P.J., 1994, "Equability," continentality, and Tertiary "climate"- the crocodilian perspective: Geology., v. 22, no. 7, p. 613-616.

McGuirk, J.P., 1979, Climate change across the Cretaceous-Tertiary boundary: Eos, Transactions, American Geophysical Union, v. 60, no. 46, p. 854. 
McKenna, M.C., 1980, Eocene paleolatitude, climate, and mammals of Ellesmere Island: Palaeogeography, Palaeoclimatology, Palaeoecology, v. 30, p. 349-362.

Miller, K.G., 1991, The Paleocene/Eocene boundary in the context of Paleocene global climate change: Geological Society of America (1991 annual meeting) Abstracts with Programs, p. 141.

Molnar, P., and England, P., 1990, Late Cenozoic uplift of mountain ranges and global climate change-chicken or egg?: Science, v. 346, p. 29-34.

Otto, B.B.L., and Upchurch, G.R., Jr., 1995, Paleovegetation and global climate change at the Cretaceous-Tertiary boundary - a global climate modeling study: Eos, Transactions (1995 spring meeting), American Geophysical Union, p. 181-182.

Pocknall, D.T., 1989, Late Eocene to early Miocene vegetation and climate history of New Zealand, in King, C.M., ed., Proceedings of the Symposium, Time, Change and the Vegetation of New Zealand; Part 1: Journal of the Royal Society of New Zealand, Wellington, New Zealand, p. 1-18.

Pocknall, D.T., 1990, Palynological evidence for the early to middle Eocene vegetation and climate history of New Zealand, in Truswell, E.M., and Owen, J.A., eds., the Proceedings of the 7th International Palynological Congress, Part II: Amsterdam, Netherlands, Elsevier, Review of Palaeobotany and Palynology, p. 57-69.

Preisinger, A., Aslanian, S., OberhÄnsli, H., and Stradner, H., 1996, Climate change after the $\mathrm{K} / \mathrm{T}$-impact, in The Cretaceous-Tertiary boundary: biological and geological aspects: Séance Spécialisée de la Société Géologique de France [unpaginated], Paris.

Raymo, M.E., and Ruddiman, W.F., 1992, Tectonic forcing of late Cenozoic climate: Nature, v. 359, p. 117-122.

Retallack, G.J., 1996, Acid trauma at the Cretaceous-Tertiary boundary in eastern Montana: GSA Today, v. 6, no. 5, p. 2-7.

Retallack, G.J., 1997, Early forest soils and their role in Devonian global change: Science, v. 276, p. 583-585.

Ruddiman, W.F., 1990, Changes in climate and biota on geologic time scales: TREE, v. 5, no. 9, p. $285-288$.

Schultz, P.H., Zarate, M., Hames, W., Camilion, C., and King, J., 1998, A 3.3-ma impact in Argentina and possible consequences: Science, v. 282, p. 2061-2063.

Spicer, R.A., 1987, The significance of the Cretaceous flora of northern Alaska for the reconstruction of the climate of the Cretaceous: Geol. Jb., v. A96, p. 265-291.

Spicer, R.A., and Chapman, J.L., 1990, Climate change and the evolution of high-latitude terrestrial vegetation and floras: TREE, v. 5, no. 9, p. 280-284.

Stott, L.D., 1992, Higher temperatures and lower oceanic $\mathrm{CO}_{2}$ : A climate enigma at the end of the Paleocene epoch: Paleoceanography, v. 7, no. 4, p. 395-404.

Stott, L.D., and Kennett, J.P., 1990, The paleoceangraphic and paleoclimatic signature of the Cretaceous/Paleogene boundary in the Antarctic - stable isotopic results from ODP LEG 113, Proceedings of the Ocean Drilling Program, Scientific Results, p. 829-845.

Stott, L.D., Sinha, A., Thiry, M., Aubry, M.-P., and Berggren, W.A., 1996, Global $\delta^{13}$ C changes across the Paleocene-Eocene boundary—criteria for terrestrial-marine correlations, in 
Knox, R.W.O.B., Corfield, R.M., and Dunay, R.E., eds., Correlation of the early Paleogene in northwest Europe: Geological Society Special Publication, p. 381-399.

Tarduno, J.A., Brinkman, K.B., Renne, P.R., Cottrell, R.D., Scher, H., and Castillo, P., 1998, Evidence for extreme climatic warmth from Late Cretaceous Arctic vertebrates: Science, v. 282, p. 2241-2244.

Upchurch, G.R., Jr., 1987, Mid-Cretaceous to early Tertiary vegetation and climate: Evidence from fossil leaves and wood, in Friis, E.M., Chaloner, W.G., and Crane, P.R., eds., The origins of angiosperms and their biological consequences: Cambridge, Cambridge University Press, p. 75-106.

Wing, S.L., and Greenwood, D.R., 1993, Fossils and fossil climate: The case for equable continental interiors in the Eocene: Philosophical Transactions of the Royal Society of London, v. 341, p. 243-252.

Wolfe, J.A., and Upchurch, G.R., Jr., 1987, Maestrichtian-Paleocene vegetation and climate of the Powder River Basin, Wyoming and Montana: Geological Society of America (1987 annual meeting) Abstracts with Programs, p. 896.

\section{Reference Work}

Kelmelis, J.A., Lins, H.F., Pettinger, L.R., Poore, R.Z., and Snow, K.M., 1992, Bibliography for the U.S. Survey Global Change and Climate History Program: U. S. Geological Open-File Report, 36 p. 